Review

\title{
Significance and Therapeutic Value of miRNAs in Embryonal Neural Tumors
}

\author{
Tarek Shalaby *, Giulio Fiaschetti, Martin Baumgartner and Michael A. Grotzer \\ Department of Oncology, University Children's Hospital of Zurich, Zurich 8008, Switzerland \\ * Author to whom correspondence should be addressed; E-Mail: tarek.shalaby@kispi.uzh.ch; \\ Tel.: +41-44-634-88-20; Fax: +41-44-634-88-59.
}

Received: 3 March 2014; in revised form: 25 April 2014 / Accepted: 28 April 2014 /

Published: 6 May 2014

\begin{abstract}
Embryonal tumors of the nervous system are the leading cause of childhood cancer-related morbidity and mortality. Medulloblastoma, supratentorial primitive neuroectodermal tumors, atypical teratoid/rhabdoid tumor and neuroblastoma account for more than $20 \%$ of childhood malignancies and typify the current neural embryonal tumor model in pediatric oncology. Mechanisms driving the formation of these tumors point towards impaired differentiation of neuronal and neuron-associated cells during the development of the nervous system as an important factor. The importance of microRNAs (miRNAs) for proper embryonic cell function has been confirmed and their aberrant expressions have been linked to tumor development. The role of miRNAs in controlling essential regulators of key pathways implicated in tumor development makes their use in diagnostics a powerful tool to be used for early detection of cancer, risk assessment and prognosis, as well as for the design of innovative therapeutic strategies. In this review we focus on the significance of miRNAs involved in the biology of embryonal neural tumors, delineate their clinical significance and discuss their potential as a novel therapeutic target.
\end{abstract}

Keywords: embryonal tumors; microRNAs; medulloblastoma; sPNET; AT/RT; neuroblastoma

\section{Introduction}

Embryonal tumors refer to a broad heterogeneous group of childhood malignancies that account for approximately $30 \%$ of childhood malignancies, including neuronal tumors of the central and peripheral 
nervous system, in addition to other rare subtypes, such as rhabdomyosarcomas, Wilms' tumor, and retinoblastoma [1]. Advances in cancer biology research have increasingly linked pediatric neoplasms with disordered mechanisms of normal development, supporting the model of embryonal tumorigenesis, both processes involve self-renewal and precisely coordinated proliferation, differentiation and cell migration [2]. The significances of miRNA-mediated regulation of gene expression during early embryogenesis and those that were linked to tumorigenesis have been established in human embryonal stem cells [3-21]. Based on these sightings, specific miRNA genes responsible for the control of embryonal stem cell proliferation and differentiation have been identified, which were also found to contribute to the initiation and progression of cancer stem cells [22-26]. Although the role of miRNA function in embryonal tumor development is still not completely understood, it is becoming clear that miRNAs are essential regulators of many of the key pathways implicated in the pathogenesis and progression of pediatric nervous system tumors [27]. This review focuses on the current understanding of the role miRNAs play in embryonal tumor development and progression, and will discuss their potential as new therapeutic targets.

\section{Embryonal Tumors of the Central and Peripheral Nervous System}

Embryonal tumors differ fundamentally from adult onset cancers, both in their cell biology and their tissue environment. They develop and manifest early in childhood and are usually characterized by a high rate of mortality and treatment-related morbidity [28]. Embryonal CNS tumors are a collection of biologically heterogeneous lesions that share the tendency to disseminate throughout the nervous system via cerebrospinal fluid (CSF). Embryonal CNS tumors include medulloblastoma (a malignant invasive tumor of the cerebellum), CNS primitive neuroectodermal tumors (a heterogeneous group of tumors arising in the cerebral hemispheres, brain stem or spinal cord), and atypical teratoid/rhabdoid tumors (AT/RT; a highly malignant CNS tumor predominantly manifesting in young children) [29]. Neuroblastoma (NB) — the most common extra-cranial embryonal tumor of childhood - arises in the sympathetic nervous system.

\section{3. microRNAs}

miRNAs are small non-coding RNAs that act as expression regulators of genes involved in fundamental cellular processes, such as development, differentiation, proliferation, survival and death [30]. Over the past few years, specific miRNAs have been reported to be implicated in various human cancers including brain tumors [9-21]. miRNAs were linked to tumorigenesis due to the fact that 50\% of the miRNAs genes are located at genomic sites associated with cancer-specific chromosomal rearrangements as well as due to the proximity of their genes to chromosomal breakpoints [31,32]. It has been found that miRNAs have the ability, in the context of human cancer, to behave like oncogenes or tumor suppressors, a finding which has important implications for cancer etiology and diagnosis [33-35]. Both losses and gains of miRNA functions through deletions, amplifications and mutations in miRNA loci or epigenetic silencing can contribute to cancer development [36]. The frequent aberrant expression and functional implication of miRNAs in human cancers have lifted these small cellular components to the ranks of preferred drug targets that operate by a new mechanism of action. 


\section{4. miRNAs in Embryonic Cell Function and Tumor Development}

Increasing evidence suggests that embryogenesis and tumorigenesis display common characteristics. Both processes involve self-renewal and proliferation, differentiation and cell migration. Based on these parallels, researchers have begun to examine the role of miRNAs in neural precursor development and cell fate determination in order to determine whether brain developmental pathways are linked to brain tumor etiology [37]. Numerous publications demonstrate the importance of the developmental effects that are related to the miRNA-mediated regulation of gene expression during early embryogenesis in different species including C. elegans, Drosophila, Zebrafish and mice [38-47]. In humans, experimental data shows that miRNAs control the fate of human ESCs during early development [39,48-54]. Human ESCs for example, express a unique microRNAs (miR-200c, 368, $154^{*}, 371,372,373^{*}, 373$ ) [42] that might serve as molecular markers for the undifferentiated stem cells in early embryonic stage. The importance of miRNAs in the development of the mammalian nervous system was demonstrated in mouse mutants lacking the activity of Dicer, the type III RNAse that is necessary for miRNA biogenesis, which die at embryonic day 7, reviewed in [55]. Using zebrafish as a model, researchers discovered that specific miRNAs such as miR-92b, miR-124, miR-222, miR-218a, miR-26 and miR-29, miR-9 are expressed differentially between neural precursors and stem cells [56,57]. In differentiating embryonic stem cells of mammals, miRNAs that are specifically expressed or enriched in brain tissues, such as let-7a, miR-218, and miR-125, miR-200a, miR-200b, miR-429, miR138 and miR-141 with miR-124 and miR-9, were found to increase sharply in abundance during the transition from neuronal precursors to neurons [41,44,58-67]. Studying the expression pattern of miRNAs during mammalian brain development, Kim et al. [68] identified eight miRNAs (miR-103, -124a, -128, -323, -326, -329, -344, -192-2) to be temporally expressed in the rat cortex and cerebellum during neural differentiation and development [69]. In another study, using human embryonic cells that differentiate into neurons upon retinoic acid treatment, Sempere et al. showed that miR-9/9, -103-1, -124a, -124b, -128, -135, -156, -218 were co-ordinately induced during the neural differentiation process [60]. Some of these miRNAs are the same as the candidates Kim and colleagues showed to be developmentally regulated in rat brain corticogenesis, indicating important roles for these miRNAs in neuronal cell fate specification and differentiation. Remarkably some of these miRNAs were reported to be also active in neuron-developmental disorders [70].

The notion that cancer is fuelled by self-renewing stem cells is gaining prominence, and so is the idea that miRNA can direct cell fate. Yu F. et al. recently brought the two fields together by showing that a single miRNA molecule "miRNA let-7" can regulate stemness in breast cancer cells [22]. The important role of stem cells both in tissue and cancer development has driven much of the research into neural cancer stem cell biology. This research recently led to the identification of specific miRNA genes responsible for ESCs proliferation and differentiation and for the initiation and progression of cancer stem cells [22-26]. Silber et al. reported that miR-124 and miR-137 induce differentiation of neural stem cells and glioblastoma stem cells [25]. Desanomi et al. reported that miR-34 deficiency is involved in the self-renewal and survival of cancer stem cells and in cancer cells lacking functional p53, restoration of miR-34 was able to re-establish the tumor suppressing signaling pathway [26]. Amazingly, specific miRNAs such as miR-302 were recently found to be capable of reprogramming the cancer cells back into a pluriopotent embryonic stem cell-like state, which then could be induced 
into tissue-specific mature cells [71]. Together these reports suggest that miRNA expression is vital for normal as well as abnormal ECS development that can lead to cancer stem cell initiation, reviewed in [26].

Cancer stem cells have been identified, isolated and characterized recently in embryonal neural malignancies including MB [72-76]. With the knowledge that MB harbors cancer-initiating cells with stem cell properties, scientists are making a great effort to understand the involvement of aberrantly expressed miRNAs in embryonal cancer stem cells and to elucidate the mechanisms, which distinguish these cells from normal stem cells. Functional studies on miRNAs within the cancer stem cells of MB will be crucial for elucidating the mechanisms behind oncogenesis in these deadly malignancies. The gained insight might reveal novel therapeutic targets, whose inhibition could impact the cancer-initiating cells and thus greatly reduce the risk of cancer relapse.

\section{Role of miRNAs in Embryonal Neuronal Tumors}

\subsection{Medulloblastoma}

$\mathrm{MB}$ is the most common malignant tumor of the central nervous system and represents more than $20 \%$ of all pediatric brain tumors [77]. MB is an invasive embryonal tumor of the cerebellum with an inherent tendency to metastasize via the subarachnoidal space [29]. Five histological varieties are recognized in the 2007 WHO classification: classic, anaplastic, large cell anaplastic, desmoplastic/nodular variant and MB with extensive nodularity [78]. Associations have been made between histopathological subtype and clinical outcomes. Patients with classical tumors tend to have average clinical outcomes, while desmoplastic/nodular MBs are associated with improved survival [78,79]. In contrast, large cell and anaplastic histologies predict shorter survival [79,80]. Several groups around the world have demonstrated that $\mathrm{MB}$ is not one disease but comprises a collection of distinct molecular subgroups. The current consensus is that there are four core subgroups, which should be termed WNT, SHH, Group 3 and Group 4 [81-84]. Kool and colleagues performed recently a meta-analysis of all molecular and clinical data of $550 \mathrm{MBs}$ brought together from seven independent studies [85]. All cases were analyzed by gene expression profiling and for validation purposes they compared the results of this meta-analysis with another large (402) MB cohort for which subgroup information was obtained by immuno-histochemistry. The results from both cohorts were highly similar and confirmed the existence of the four MB subgroups and showed how distinct the molecular subtypes are with respect to their transcriptome [85]. Linking the subgroups to clinical follow-up data demonstrated that WNT and SHH carry favorable outcomes while group 3 and 4 are associated with poor prognosis $[81,82,84,86,87]$. The best outcome was found for WNT tumors. Interestingly, metastatic disease at diagnosis is also significantly associated with non-WNT/SHH tumors and most strongly with group 3 tumors $[81,82,84]$.

\subsection{1. miRNAs Aberrantly Expressed in MB}

Despite the intense investigation in the involvement of miRNAs in a variety of cancer types, knowledge of their role in MB pathogenesis has only recently started to build up. Pierson et al. [88] was the first to report the involvement of miRNA in MB. The authors found that the expression of 
miR-124a - a brain enriched miRNA preferentially expressed in mature neurons and in external granule cells of the cerebellum, which were reported to be cells of origin of MBs [44,65,67] - is significantly decreased in MB cells compared to normal cerebellum. Similar decreases were also observed in other brain tumors [25,69]. Interestingly restoration of miR-124 function inhibits MB cell proliferation, suggesting that it may act as a suppressor of tumor growth. In a computational-based approach to predict miR-124 target genes, Pierson et al. discovered and validated cyclin dependent kinase 6 (CDK6) that was identified as an adverse prognostic marker in MB and solute carrier family 16, member 1(SLC16A1) that may represent a novel therapeutic target for treatment of malignant MBs [89,90]. In a parallel but distinct study Ferretti et al. [27] used high-throughput screening to examine miRNA expression profiles in 34 patients with MB. Their investigation revealed a set of 78 miRNAs with altered expression in MB, compared to normal adult and fetal cerebellar samples. Amazingly the authors identified a unique set of four up-regulated miRNAs (let-7g, miR-19a, miR-106b and miR-191) that are capable of distinguishing anaplastic variants from classic and/or desmoplastic MBs. Moreover, the authors found a number of developmentally regulated miRNAs that maintained levels of expression in $\mathrm{MB}$ similar to those observed in fetal cerebellum, supporting the notion that MBs exhibit some embryonic features. In MB samples they observed for example impaired expression of several neuronal miRNAs known to be expressed during neuronal development such as (miR-9 and miR-125a, miR-128a, 128b and miR-181b) suggesting that some of these miRNAs might be involved in MB tumorigenesis [91]. Notably all of these miRNAs with altered expressions were identified before in glioblastomas [92], suggesting a common role for these miRNAs in the etiology of malignant brain tumors. The authors selected miR-9 and miR-125a, as down-regulated neuronal candidates, for functional studies. Ectopic over-expression of miR-9 or miR-125a decreased proliferation, augmented apoptosis, and promoted arrest of $\mathrm{MB}$ tumor growth suggesting a role for both miRNAs as tumor suppressors [93]. These miRNAs mediated their effects through targeting of the pro-proliferative truncated isoform of the neurotrophin receptor TrkC, which is up-regulated in $\mathrm{MB}$ cells. Such findings are in line with those observed in neuroblastomas [91,94]. Consistently, other miRNAs in pediatric brain tumors including MB, such as miR-216, miR-135b, miR-217, miR-592, miR-340 were found to be over-expressed, whereas miR-92b, miR-23a, miR-27a, miR-146b, miR-22) were found to be underexpressed compared to normal brain tissues [95].

In addition to their role in promoting the development of primary tumors, miRNAs have also been implicated in the metastatic dissemination of tumor cells and alterations in miRNA function can influence metastatic potential $[96,97]$. Among several pro-metastatic miRNAs, miR-21 is up-regulated in a variety of solid tumors, including glioblastoma, breast, lung, colon, prostate, pancreas and stomach cancers [98] and has been causally linked to cell migration of several cancer cell lines [99]. We recently reported the aberrant expression of miR-21 in MB cells and showed that miR-21 regulated the expression of multiple target proteins associated with tumor dissemination, many of which are implicated in MB biology [100]. Importantly, repression of miR-21 decreased MB cell migration in vitro, possibly due to diminished repression of the tumor suppressor PDCD4. Thus, miR-21 could function as a pro-metastatic miRNA in MB and therefore raising the possibility that pharmaceutical strategies directed against miR-21 could improve the curability of selected MBs (Tables 1 and 2). 
Table 1. Frequently deregulated miRNAs in neuronal embryonal tumors.

\begin{tabular}{|c|c|c|c|c|}
\hline Tumor & $\begin{array}{l}\text { miRNA } \\
\text { regulation }\end{array}$ & $\begin{array}{l}\text { Validated or } \\
\text { putative targets }\end{array}$ & Potential function & References \\
\hline \multirow{14}{*}{$\begin{array}{l}\text { MB } \\
\text { Reviewed } \\
\text { in [101- } \\
\text { 104] }\end{array}$} & $\begin{array}{l}\operatorname{miR}-17 / 92 \\
\mathrm{Up}\end{array}$ & $\begin{array}{l}\text { TSP-1, Bmi-1, PTEN, } \\
\text { PP2A }\end{array}$ & $\begin{array}{l}\text { Enhances proliferation, angiogenesis and } \\
\text { confers growth advantage to MBs }\end{array}$ & {$[90,105,106]$} \\
\hline & $\begin{array}{l}\text { Let-7 } \\
\text { Down }\end{array}$ & $\begin{array}{l}\text { RAS } \\
\text { STAT3 }\end{array}$ & $\begin{array}{l}\text { Disregulation leads to a less differentiated } \\
\text { cellular state }\end{array}$ & {$[107,108]$} \\
\hline & $\begin{array}{l}\text { miR-199b-5p } \\
\text { Down }\end{array}$ & $\begin{array}{l}\text { HES1 } \\
\text { Notch pathway } \\
\text { ErbB2 }\end{array}$ & $\begin{array}{l}\text { Inhibits tumor growth and metastasis. Its } \\
\text { restoration blocks expression of several cancer } \\
\text { stem-cell genes }\end{array}$ & [109] \\
\hline & $\begin{array}{l}\text { miR-34a } \\
\text { Down }\end{array}$ & $\begin{array}{l}\text { Notch ligand Delta-like } \\
1 \text { (Dl11) }\end{array}$ & $\begin{array}{l}\text { Negatively regulates cell proliferation, and } \\
\text { induces apoptosis and neural differentiation in } \\
\text { MB cells }\end{array}$ & {$[110]$} \\
\hline & $\begin{array}{l}\operatorname{miR}-214 \\
\text { Up }\end{array}$ & Gli1 & Undefined & {$[27]$} \\
\hline & $\begin{array}{l}\operatorname{miR}-125 \mathrm{a} \\
\text { Down }\end{array}$ & $\mathrm{t}-\mathrm{TrkC}$ & $\begin{array}{l}\text { Its restoration decreases proliferation, augments } \\
\text { apoptosis, and promotes arrest of MB tumor cell } \\
\text { growth. }\end{array}$ & {$[107]$} \\
\hline & $\begin{array}{l}\text { miR-9 } \\
\text { Down }\end{array}$ & REST/NRSF, Hes1 & $\begin{array}{l}\text { Inhibits MB cell proliferation and promotes } \\
\text { differentiation }\end{array}$ & {$[107,111]$} \\
\hline & $\begin{array}{l}\operatorname{miR}-125 b \\
\text { miR-324-5p } \\
\text { miR-326 } \\
\text { Down } \\
\end{array}$ & PKM2, SMO, Notch & $\begin{array}{l}\text { Inhibits } \mathrm{MB} \text { cell proliferation, and reduces the } \\
\text { size and number of } \mathrm{MB} \text { cell colonies }\end{array}$ & {$[27,112]$} \\
\hline & $\begin{array}{l}\operatorname{miR}-124 a \\
\text { Down }\end{array}$ & $\begin{array}{l}\text { CDK6, SLC16A1, } \\
\text { REST, BAF34a, RB1, t- } \\
\text { TrkC }\end{array}$ & $\begin{array}{l}\text { Cell cycle regulation. Inhibits proliferation and } \\
\text { induces apoptosis }\end{array}$ & $\begin{array}{l}{[25,65,88,113,} \\
114]\end{array}$ \\
\hline & $\begin{array}{l}*(\mathrm{miR}-30 \mathrm{~b} \text { and } \\
\text { miR-30d) } \\
\mathrm{Up}\end{array}$ & $\begin{array}{l}\text { Undefined } \\
\text { Both miRNAs are part } \\
\text { of an amplicon } \\
\text { containing the } \\
\text { KHDRBS3 gene on } \\
\text { 8q24.22 in MB cell lines }\end{array}$ & Undefined & {$[115]$} \\
\hline & $\begin{array}{l}\text { miR-218 } \\
\text { Down }\end{array}$ & $\begin{array}{l}\text { EGFR, Bcl-2, B-catenin } \\
\text { and MAPK9 }\end{array}$ & $\begin{array}{l}\text { Iinduces apoptosis, inhibits MB tumor growth } \\
\text { and invasiveness }\end{array}$ & {$[116,117]$} \\
\hline & $\begin{array}{l}* \text { miR-31 and } \\
\text { miR-153 } \\
\text { Down }\end{array}$ & $\begin{array}{l}\text { Undefined. however, } \\
\text { miR-153 is found in } \\
\text { high ErbB2 expressing } \\
\text { MB }\end{array}$ & Undefined & {$[107,117]$} \\
\hline & $\begin{array}{l}\text { miR-106b } \\
\text { Up }\end{array}$ & $\mathrm{p} 21$ & Cell cycle arrest & {$[107,116]$} \\
\hline & $\begin{array}{l}\operatorname{miR}-128 \mathrm{a} \\
\operatorname{miR}-128 \mathrm{~b} \\
\operatorname{miR}-181 \mathrm{~b} \\
\text { Down }\end{array}$ & Bmi-1 & $\begin{array}{l}\text { Inhibits growth of MB cells. } \\
\text { miR-128a, alters the intracellular redox state and } \\
\text { promotes cellular senescence in MB cancer stem } \\
\text { cells, which are thought to be resistant to } \\
\text { therapy due to their low ROS states }\end{array}$ & {$[91,118]$} \\
\hline
\end{tabular}


Table 1. Cont.

\begin{tabular}{|c|c|c|c|c|}
\hline Tumor & $\begin{array}{l}\text { miRNA } \\
\text { regulation }\end{array}$ & $\begin{array}{l}\text { Validated or } \\
\text { putative targets }\end{array}$ & Potential function & References \\
\hline \multirow{5}{*}{$\begin{array}{l}\text { MB } \\
\text { Reviewed } \\
\text { in }[101- \\
104]\end{array}$} & $\begin{array}{l}\operatorname{miR}-21 \\
\mathrm{Up}\end{array}$ & PDCD4. & $\begin{array}{l}\text { Pro-metastatic miRNA in MB. Involved } \\
\text { in mitotic signaling, cell cycle, cell } \\
\text { migration }\end{array}$ & {$[100]$} \\
\hline & $\begin{array}{l}\text { miR-183 96 182 } \\
\text { cluster } \\
\text { Up }\end{array}$ & $\begin{array}{l}\text { Undefined, however knockdown } \\
\text { of the full miR-183 96 182 } \\
\text { cluster results in enrichment of } \\
\text { genes associated with apoptosis } \\
\text { and dysregulation of the } \\
\text { PI3K/AKT/mTOR signaling axis }\end{array}$ & $\begin{array}{l}\text { Regulates multiple biological programs } \\
\text { that converge to support the } \\
\text { maintenance and metastatic potential of } \\
\text { MB }\end{array}$ & [119] \\
\hline & $\begin{array}{l}* \text { miR-216, } \\
\text { miR-135b, miR-217, } \\
\text { miR-592, miR-340 } \\
\text { Up }\end{array}$ & Undefined & Undefined & [95] \\
\hline & $\begin{array}{l}* \operatorname{miR}-92 b, \operatorname{miR}-23 a \\
\text { miR-27a, miR-146b, } \\
\text { miR-22 } \\
\text { Down }\end{array}$ & Undefined & Undefined & [95] \\
\hline & $\begin{array}{l}\operatorname{miR}-148 \mathrm{a} . \\
\text { Up. }\end{array}$ & Undefined & Undefined & [120] \\
\hline \multirow{2}{*}{$\begin{array}{l}\text { sPNET } \\
{[103]}\end{array}$} & $\begin{array}{l}* \mathrm{miR}-517 \mathrm{cmiR}- \\
520 \mathrm{~g} \\
\mathrm{Up}\end{array}$ & Undefined & Undefined & [121] \\
\hline & $\begin{array}{l}* \text { miR-19a, miR- } \\
106 \mathrm{~b} \text { and miR-19 } \\
\text { Up }\end{array}$ & Undefined & Undefined & [107] \\
\hline \multirow{6}{*}{$\mathrm{AT} / \mathrm{RT}$} & $\begin{array}{l}\text { miR-9 } \\
\text { Down }\end{array}$ & Undefined & Undefined & {$[107,111]$} \\
\hline & $\begin{array}{l}\mathrm{miR}-517 \mathrm{c}, \mathrm{miR}-520 \mathrm{~g} \\
\text { Up }\end{array}$ & $\begin{array}{l}\text { miR-517c WNT/JNK signaling } \\
\text { miR-520g ABCG2. }\end{array}$ & Undefined & {$[121,122]$} \\
\hline & $\begin{array}{l}\text { miR-221, miR-222 } \\
\text { Up }\end{array}$ & $\mathrm{p} 27^{\mathrm{Kip} 1}$ & $\begin{array}{l}\text { Promotes proliferation through cell } \\
\text { cycle progression in AT/RT cells }\end{array}$ & [123] \\
\hline & $\begin{array}{l}* \text { miR-520b, miR- } \\
629, \text { miR-498, miR- } \\
373 \\
\text { Up }\end{array}$ & Undefined & Undefined & [95] \\
\hline & $\begin{array}{l}* \text { miR-140, let-7b, } \\
\text { miR-139, miR-153, } \\
\text { miR-376b } \\
\text { Down }\end{array}$ & Undefined & Undefined & {$[95]$} \\
\hline & $\begin{array}{l}\text { let-7 miRNA family } \\
\text { Down }\end{array}$ & HMGA2 & $\begin{array}{l}\text { Suppresses proliferation and colony } \\
\text { formation and abolishes the invasive } \\
\text { potential }\end{array}$ & [124] \\
\hline
\end{tabular}


Table 1. Cont.

\begin{tabular}{|c|c|c|c|c|}
\hline Tumor & $\begin{array}{l}\text { miRNA } \\
\text { regulation }\end{array}$ & $\begin{array}{l}\text { Validated or } \\
\text { putative targets }\end{array}$ & Potential function & References \\
\hline \multirow{14}{*}{$\begin{array}{l}\text { NB } \\
\text { Adapted } \\
\text { from } \\
{[102]}\end{array}$} & $\begin{array}{l}\operatorname{miR}-17-92 \\
\text { Up }\end{array}$ & $\begin{array}{l}\text { DKK3, CDKN1A, BIM, } \\
\text { ER- } \alpha, \text { MEF2D }\end{array}$ & $\begin{array}{l}\text { Increases proliferation, decreases apoptosis } \\
\text { and inhibits TGF- } \beta \text { signaling. miR-17-5p } \\
\text { inhibition abolish growth of therapy- } \\
\text { resistant NB in vitro as well as in vivo }\end{array}$ & {$[125-131]$} \\
\hline & $\begin{array}{l}\text { miR-124 } \\
\text { Undefined }\end{array}$ & AHR & Inhibits apoptosis and differentiation & {$[127-130]$} \\
\hline & $\begin{array}{l}\text { miR-181 } \\
\text { Up }\end{array}$ & ATM & Undefined & {$[125]$} \\
\hline & $\begin{array}{l}\operatorname{miR}-21 \\
\mathrm{Up}\end{array}$ & PTEN & $\begin{array}{l}\text { Promotes proliferation, and decreases } \\
\text { sensitivity to chemotherapy }\end{array}$ & {$[127-130]$} \\
\hline & $\begin{array}{l}\operatorname{miR}-380-5 p \\
\text { Up }\end{array}$ & P53 & Decreases apoptosis & [132] \\
\hline & $\begin{array}{l}\operatorname{miR}-15 \mathrm{a} \\
\mathrm{Up}\end{array}$ & RECK & $\begin{array}{l}\text { Promotes migration through the induction of } \\
\text { MMP-9 expression }\end{array}$ & {$[133]$} \\
\hline & $\begin{array}{l}* \text { miRNA-125a/b } \\
\text { Induced } \\
\text { upon treatment with } \\
\text { RA }\end{array}$ & $\begin{array}{l}\text { Modulate expression } \\
\text { of the TrkC } \\
\text { neurotrophin receptor }\end{array}$ & Undefined & {$[94,134]$} \\
\hline & $\begin{array}{l}\text { miR-184 } \\
\text { Undefined }\end{array}$ & $\begin{array}{l}\text { Akt2 downstream } \\
\text { effector of the pro- } \\
\text { survival pathway PI3K }\end{array}$ & $\begin{array}{l}\text { Pro-apoptotic effects. Mediates proliferation } \\
\text { reduction and inhibition of tumor growth in } \\
\text { an orthotopic murine model of NB }\end{array}$ & [135] \\
\hline & $\begin{array}{l}\operatorname{miR}-128 \\
\text { Undefined }\end{array}$ & Reelin and DCX & $\begin{array}{l}\text { Mediates differentiation, reduces motility, } \\
\text { invasiveness, and growth of NB cells }\end{array}$ & {$[136]$} \\
\hline & $\begin{array}{l}\operatorname{miR}-34 a \\
\operatorname{miR}-34 c \\
\operatorname{miR}-410,487 b \\
\text { Down }\end{array}$ & $\begin{array}{l}\text { E2F3, BCL2, CCND1, } \\
\text { CDK4, } \\
\text { MYCN, P53 }\end{array}$ & $\begin{array}{l}\text { Inhibits proliferation and induces apoptosis } \\
\text { Ectopic expression of miR-34a leads to cell- } \\
\text { cycle arrest in NB lines }\end{array}$ & $\begin{array}{l}{[127,134,135,137} \\
-139]\end{array}$ \\
\hline & $\begin{array}{l}\text { miR-542-5p } \\
\text { Expressed in } \\
\text { favorable NB, absent } \\
\text { in unfavorable NB }\end{array}$ & $\begin{array}{l}\text { GRIN3A, SH3GLB2, } \\
\text { SNIP }\end{array}$ & $\begin{array}{l}\text { Inhibits tumor growth, invasiveness and } \\
\text { metastasis. }\end{array}$ & {$[125,140]$} \\
\hline & $\begin{array}{l}\text { miR- } 628 \\
\text { Expressed in } \\
\text { favorable NB, absent } \\
\text { in unfavorable NB }\end{array}$ & Undefined & Undefined & {$[125,140]$} \\
\hline & $\begin{array}{l}\text { miR-let-7 } \\
\text { Down-regulated in } \\
\text { NB with MYCN } \\
\text { amplification }\end{array}$ & MYCN & $\begin{array}{l}\text { Inhibits proliferation and induces } \\
\text { differentiation. Altered expression of let- } 7 \\
\text { leads to a less differentiated cellular state }\end{array}$ & {$[141]$} \\
\hline & $\begin{array}{l}\text { miR-101 } \\
\text { Down-regulated in } \\
\text { NB with MYCN } \\
\text { amplification }\end{array}$ & MYCN & Inhibits proliferation and clonogenic growth & {$[141]$} \\
\hline
\end{tabular}


Table 1. Cont.

\begin{tabular}{|c|c|c|c|c|}
\hline Tumor & $\begin{array}{l}\text { miRNA } \\
\text { regulation }\end{array}$ & $\begin{array}{l}\text { Validated or } \\
\text { putative targets }\end{array}$ & Potential function & References \\
\hline \multirow{13}{*}{$\begin{array}{l}\text { NB } \\
\text { Adapted } \\
\text { from } \\
{[102]}\end{array}$} & $\begin{array}{l}\text { miR-885-5p } \\
\text { Down }\end{array}$ & CDK2, MCM5 & Inhibits cell cycle progression and survival & [142] \\
\hline & $\begin{array}{l}\operatorname{miR}-27 b \\
\text { Down }\end{array}$ & $\operatorname{PPAR} \gamma$ & Inhibits tumor growth & [143] \\
\hline & $\begin{array}{l}\operatorname{miR}-138 \\
\text { Down }\end{array}$ & Undefined & Decreases viability and growth & {$[144]$} \\
\hline & $\begin{array}{l}\text { miR-137 } \\
\text { Down }\end{array}$ & KDM1A & Inhibits proliferation and induces apoptosis & {$[145]$} \\
\hline & $\begin{array}{l}\text { miR-204 } \\
\text { Down }\end{array}$ & BCL2, NTRK2. & $\begin{array}{l}\text { Increases sensitivity to cisplatin and } \\
\text { etoposide }\end{array}$ & {$[146,147]$} \\
\hline & $\begin{array}{l}\text { miR-190 } \\
\text { Down in aggressive } \\
\text { NB with unknown } \\
\text { mechanism }\end{array}$ & NEUROD1 & $\begin{array}{l}\text { Inhibits TrkB pathwayand aggressive } \\
\text { phenotypes. }\end{array}$ & [147] \\
\hline & $\begin{array}{l}\operatorname{miR}-10 \mathrm{a} / \mathrm{b} \\
\text { Down }\end{array}$ & $\begin{array}{l}\text { NCOR2 } \\
\mathrm{miR}-10 \mathrm{a} / \mathrm{b}\end{array}$ & Induces differentiation & [148] \\
\hline & $\begin{array}{l}\operatorname{miR}-335 \\
\text { Down }\end{array}$ & $\begin{array}{l}\text { ROCK1, MAPK1, } \\
\text { LRG1 }\end{array}$ & Inhibits migration and invasion & {$[149,150]$} \\
\hline & $\begin{array}{l}\text { miR-363 } \\
\text { Down }\end{array}$ & Undefined & Inhibits invasiveness and metastasis & [149] \\
\hline & $\begin{array}{l}\text { miR-9 } \\
\text { Down }\end{array}$ & MMP-14 & $\begin{array}{l}\text { Inhibits the invasion, metastasis, and } \\
\text { angiogenesis }\end{array}$ & {$[151]$} \\
\hline & $\begin{array}{l}\operatorname{miR}-145 \\
\text { Down }\end{array}$ & HIF- $2 \alpha$ & $\begin{array}{l}\text { Inhibits NB cell growth, invasion, metastasis } \\
\text { and angiogenesis }\end{array}$ & {$[152]$} \\
\hline & $\begin{array}{l}* \text { miR-140 let-7b } \\
\text { miR-139 } \\
\text { miR-153 miR-376b } \\
\text { Down }\end{array}$ & Undefined & Undefined & {$[95]$} \\
\hline & $\begin{array}{l}\text { let-7a3/let-7b } \\
\text { miRNA } \\
\text { Down }\end{array}$ & HMGA2 & Undefined & {$[124]$} \\
\hline
\end{tabular}

* Poorly characterized miRNA/s in the specific tumor setting.

Table 2. Clinical relevance of miRNAs in NB [102,125,130,131,153-159].

\begin{tabular}{llll}
\hline $\begin{array}{l}\text { miRNAs up/down regulated in } \\
\text { high-risk NB }\end{array}$ & $\begin{array}{l}\text { miRNAs } \\
\text { up-regulated in } \\
\text { metastatic NB }\end{array}$ & $\begin{array}{l}\text { miRNAs up/down regulated } \\
\text { survival of NB }\end{array}$ & $\begin{array}{l}\text { miRNAs up/down } \\
\text { regulated in }\end{array}$ \\
\hline$\uparrow \mathrm{miR}-18 \mathrm{~b}, \uparrow \mathrm{miR}-20 \mathrm{a}, \uparrow \mathrm{miR}-22$, & $\operatorname{miR}-24$, & $\uparrow \mathrm{miR}-380-5 \mathrm{p}, \uparrow \mathrm{miR}-17-92$ & $\uparrow \mathrm{miR}-181, \uparrow \mathrm{miR}-21$, \\
unfavorable NB
\end{tabular}


Table 2. Cont.

\begin{tabular}{|c|c|c|c|}
\hline $\begin{array}{l}\text { miRNAs up/down regulated in } \\
\text { high-risk NB }\end{array}$ & $\begin{array}{l}\text { miRNAs } \\
\text { up-regulated in } \\
\text { metastatic NB }\end{array}$ & $\begin{array}{l}\text { miRNAs up/down regulated } \\
\text { as a marker for poor } \\
\text { survival of NB }\end{array}$ & $\begin{array}{l}\text { miRNAs up/down } \\
\text { regulated in } \\
\text { unfavorable NB }\end{array}$ \\
\hline $\begin{array}{l}\downarrow \mathrm{miR}-146 \mathrm{a}, \downarrow \mathrm{miR}-190, \downarrow \mathrm{miR}-204, \\
\downarrow \mathrm{miR}-215, \downarrow \mathrm{miR}-299-5 \mathrm{p}, \downarrow \mathrm{miR}-362, \\
\downarrow \mathrm{miR}-382, \downarrow \mathrm{miR}-411, \downarrow \mathrm{miR}-424, \\
\downarrow \mathrm{miR}-425, \downarrow \mathrm{miR}-487 \mathrm{~b}, \downarrow \mathrm{miR}-532, \\
\downarrow \mathrm{miR}-629, \downarrow \mathrm{miR}-656, \downarrow \mathrm{miR}-660, \\
\downarrow \mathrm{miR}-668, \downarrow \mathrm{miR}-744, \downarrow \mathrm{miR}-758, \\
\downarrow \mathrm{miR}-873, \downarrow \mathrm{miR}-885-5 \mathrm{p}, \text { and } \\
\downarrow \mathrm{miR}-1197, \mathrm{miR}-30 \mathrm{c}, \downarrow \mathrm{miR}-149, \\
\downarrow \mathrm{miR}-195, \mathrm{miR}-324-5 \mathrm{p} \text { and } \\
\downarrow \mathrm{miR}-331\end{array}$ & $\begin{array}{l}\text { miR-345, } \\
\text { miR-483-3p, } \\
\text { and } \\
\text { miR-486-5p. } \\
\text { miR-17-92 }\end{array}$ & $\begin{array}{l}\text { (correlates with increased } \\
\text { event-free survival and } \\
\text { favorable disease outcome). } \\
\uparrow m i R-184 \text { (increases overall } \\
\text { survival). } \\
\uparrow m i R-204 \text { (associated with a } \\
\text { favourable clinical outcome } \\
\text { and increases sensitivity to } \\
\text { chemotherapy). }\end{array}$ & $\begin{array}{l}\downarrow \operatorname{miR}-195, \\
\downarrow \operatorname{miR}-324-5 p \downarrow \text { and } \\
\text { miR-331 }\end{array}$ \\
\hline
\end{tabular}

$\uparrow:$ Upregulated, $\downarrow$ : Downregulated.

\subsubsection{MB Subgroups Have Distinct miRNA Profiles}

Genome-wide miRNA expression studies have revealed close associations between miRNA clusters and MB tumor subtypes as well as clinical subgroups [90,107,119,160]. Additionally, miRNA profiling studies demonstrated that it is possible by miRNA signatures to discriminate MB histological subtypes. While miR-21, a known oncomir [161], was up-regulated across all MB subgroups relative to normal cerebellum, Northcott and colleagues reported that miR-17/92 cluster was found to be significantly up-regulated in SHH-driven MB [90,162]. The group concluded that miR-17/92 is a positive effector of SHH-mediated proliferation and that aberrant expression/amplification of this miRNA confers a growth advantage in a specific subpopulation of MBs. Their results were confirmed by the discovery that miR-17/92 promoted proliferation of MB cell lines in vitro and contributed to the development of MB in vivo [90,162]. In other studies microRNAs encoded by the miR-17/92 and miR-106b-25 clusters were found to be over-expressed specifically in human and mouse SHH MBs [107,163]. Consistent with its high expression in SHH MB, enforced expression of the miR-17/92 cluster, together with mutation of Ptch1+/-, accelerates the onset and penetrance of SHH MB [162]. Tumor progression can be inhibited by using miRNA inhibitors that target the seed sequence of miR-17/20 and miR-19a/b in SHH MB cells in vitro and in animals bearing flank or cortical SHH MB allografts [164]. These data suggest that miRNAs inhibitors targeting the miR-17/92 cluster family could be therapeutically useful in SHH MB and other cancers that over-express members of this cluster family [165]. Weeraratne and colleagues have reported that increased expression of the miR-183 96 182 cluster characterizes non-SHH MBs. This cluster of miRNAs was found to be associated with MB subgroups characterized by genetic amplification of MYC [119]. Remarkably, miR-182 is known to promote metastasis, a hallmark of aggressive MBs [166]. Three other microRNAs were found to be differentially regulated in MYC-over-expressing MBs compared to MBs in which MYC is not over-expressed [107]. However, whether these microRNAs are directly regulated by MYC is yet unknown, reviewed in [165]. In another publication Cho et al. discovered a previously unidentified molecular subgroup, characterized genetically by MYC copy number gains and 
transcriptionally by enrichment of photoreceptor pathways and increased miR-183-96-182 expression. This newly discovered subgroup is associated with significantly lower rates of event-free and overall survivals [167]. For the WNT MB subgroup, Gokhale et al. reported a distinctive microRNA signature associated with the WNT signaling pathway. In their study miR-193a, miR-224/miR-452 cluster, miR-182/miR-183/miR-96 cluster, and miR-148a having potential tumor/metastasis suppressive activity were found to be over-expressed in the WNT signaling associated MB [120].

In summary, the altered miRNA expression signatures in distinct MB subtypes highlight the functional significance of these novel oncogenic molecules in MB tumor formation and progression. Such discoveries not only provide new insights into the molecular pathogenesis of MB tumors, but also raise hopes for translating the increasing knowledge of miRNA expression and functions into diagnosis, prognostication and therapy.

\subsection{Supratentorial Primitive Neuroectodermal Tumors}

The supratentorial primitive neuroectodermal tumors (sPNET), which represent $3 \%-7 \%$ of all pediatric brain tumors, are a group of highly malignant lesions primarily affecting young children. Although these tumors are histologically indistinguishable from infratentorial MB, they often respond poorly to MB-specific therapy [168]. Indeed, the very few existing molecular genetic studies indicate that SPNET have cytogenetic profiles that are different from those of MBs, thus pointing to unique biological derivation for the supratentorial PNET. sPNET are a heterogeneous group characterized by primitive neuroepithelial cells with variable neuronal, glial, or ependymal differentiation [121]. Unlike AT/RT, which are defined by INI1 gene alterations [169], sPNET may pose significant diagnostic challenges due to lack of characteristic genetic or immunohistochemical markers [121]. Due to the shortage of these tumors, comprehensive genetic studies of a substantial number of sPNETs have not yet been undertaken. Therefore, the lack of insight into the molecular pathogenesis of sPNET has become a major obstacle toward development of disease-specific models and treatments.

miRNAs Aberrantly Expressed in sPNET

Owing to the rarity of these tumors and disagreement about their histopathological diagnoses, very little is known about the molecular characteristics of sPNET. Additionally, the role of miRNAs in sPNET was not yet established until recently [170]. The chromosome 19 microRNA cluster (C19MC) is the largest human microRNA gene cluster described so far. This miRNA cluster spans $100 \mathrm{~kb}$ at human chromosome 19q13.42 and comprises 54 tandemly repeated miRNA genes [171]. Amplification of a miRNA cluster at 19q13.42 has been identified recently as a genetic hallmark of sPNET, and it is considered a unifying molecular diagnostic marker for these tumors [121,171,172]. Very recently Li et al. established that amplification of C19MC was present in aggressive sPNET tumor cells [121]. They showed that miR-517c and/or $520 \mathrm{~g}$ in the C19MC group could stimulate growth and prevent development of normal human neural stem cells into more mature types of brain cells. They also reported that constitutive expression of miR-517c or $520 \mathrm{~g}$ promotes in vitro and in vivo oncogenicity. Furthermore, the group showed that C19MC miRNA oncogenes may confer aggressive tumor phenotype by altering signaling pathways that regulate normal neural stem cell growth. Their data describe for the first time miR-517c and $520 \mathrm{~g}$ as oncogenes in sPNET and highlight C19MC as an 
attractive candidate biomarker and therapeutic target for aggressive pediatric brain tumors. Interestingly, Kleinman and colleagues reported recently that embryonal tumors with multilayered rosettes (ETMR), an aggressive pediatric brain tumors of sPNET variant that originate from early neural stem cell precursors, are characterized by a recurrent fusion that joins the promoter of a gene with brain-specific expression (TTYH1) to C19MC. This fusion event, which is unique to ETMRs, drives high levels of expression of the miRNA cluster in these tumors, reawakening a transcriptional program that is normally only active during the early stages of embryonic development $[173,174]$. Together these findings support the emerging theme that miRNAs are important determinants of sPNET embryonal tumor biology.

\subsection{Atypical Teratoid/Rhabdoid Tumors (AT/RT)}

AT/RT are rare but highly aggressive tumors that typically occur in infancy or early childhood [175,176]). Rhabdoid tumors predominantly arise in the kidney and brain, but they can also be found in a deep axial location, such as the neck or the paraspinal region [177]. Different forms of rhabdoid tumors can be similar in their aggressiveness, histological features, and loss of function of INI1/hSNF5 mapping on chromosome 22 [178,179]. From the clinical experience, infants and children with rhabdoid tumors respond very poorly to chemotherapy and radiotherapy [180-182], although this remarkable resistance to both cytostatic drugs and radiotherapy has not yet found convincing explanation at the molecular level.

\section{miRNAs Aberrantly Expressed in AT/RT}

To find new potential therapeutic targets for the treatment of AT/RT, Sredni and colleagues [123] investigated differentially expressed miRNAs when comparing four AT/RT with six MB and normal brain samples. Within the top differentially expressed miRNAs, the deregulated expression of miR221/222 was demonstrated to inhibit the expression of the tumor suppressor and inhibitor of cell cycle p27Kip1. These results suggest that miR-221/222 over-expression might be one of the factors contributing to oncogenesis and progression of AT/RT through p27Kip1 down-regulation. The authors suggested that anti-miR221/222 therapy might be an option for the treatment of these very aggressive and unresponsive tumors. In a comprehensive study Birks et al. [95] compared miRNAs expression in pediatric brain tumors and normal tissue controls by microarray. Their result showed that miR-129, miR-142-5p, and miR-25 were differentially expressed in every pediatric brain tumor type compared to normal tissue controls. In AT/RT miR-520b, miR-629, miR-221, miR-498, miR-373* were up-regulated while miR-140, let-7b, miR-139, miR-153, miR-376b were under-expressed. Zhang et al. [124] have recently searched for novel genomic aberrations by investigating the copy number and expression alterations of let-7a3/let-7b miRNA and correlated these with expression of high-mobility group AT-hook 2 (HMGA2) oncoprotein, a target of let-7 miRNA family, in 18 AT/RT samples. Their analysis demonstrated that HMGA2 was highly over-expressed in $83.3 \%(15 / 18)$ of AT/RT tissues while let-7a3/let-7b miRNA copy number and expression were reduced. Restoration of let-7 miRNA or knockdown of HMGA2 expression significantly suppressed proliferation and colony formation and almost abolished the invasive potential of G401 Wilms' tumor cell line. The authors suggested that 
HMGA2 oncoprotein plays critical roles in the pathogenesis of AT/RT development and reconstitution of let-7 miRNA may provide a novel therapeutic strategy for the treatment of AT/RT patients.

\subsection{Neuroblastoma}

NB is the most common extra-cranial solid tumor in childhood, accounting for approximately $7 \%-10 \%$ of pediatric cancers and $15 \%$ of all cancer-related deaths in patients less than 15 years old [183-185]. $\mathrm{NB}$ is an extremely heterogeneous disease both biologically and clinically $[183,184,186]$. NB is thought to be an embryonal tumor that is derived from precursor cells of the peripheral (sympathetic) nervous system [2,187]. The tumor can arise anywhere along the sympathetic chain but is most frequently in the adrenal medulla and paraspinal ganglia [187,188] reviewed in [189]. The clinical outcome of NB can range from complete regression (mainly in infants) to rapid tumor progression and metastasis with poor prognosis [190]. Many genetic abnormalities have been identified in NB tumors, including amplification of the MYCN proto-oncogene (25\%-33\% of patients) and consistent areas of chromosomal deletion and rearrangement that result in loss of $1 \mathrm{p} 36(25 \%-35 \%), 11 \mathrm{q} 23(35 \%-45 \%)$, and $14 \mathrm{q} 23(16 \%-27 \%)$, as well as unbalanced gain of 17q22 ( 50\%). Many of these abnormalities are powerful prognostic markers and are highly related to clinical outcome. For example, NB tumors which harbor 1p36 LOH and MYCN amplification are usually advanced-stage aggressive tumors that are frequently metastatic and generally respond poorly to chemotherapy/irradiation [183,184]. Amplified $M Y C N$ has been proposed as an example of the first clinical application of cellular oncogenes, and is now established as a powerful molecular parameter to determine patient prognosis, as well as a basis for patient stratification [183,191,192].

\section{MicroRNAs Aberrantly Expressed in NB}

Aberrant regulation of miRNA expression has been implicated in the pathogenesis of NB (Tables 1 and 3), and miRNA expression profiles have been correlated with prognosis, and cell differentiation, and apoptosis [193], suggesting that miRNAs could function as tumor suppressors or oncogenes in NB. Guo et al. compared miRNA expression patterns of primary and metastatic NB tumors and found significant changes of 54 miRNAs [153]. MiR-10b, miR-29a/b, miR-335, which are known to promote metastasis were up-regulated in metastatic NB tumors. In contrast, miR-7, miR-338-3p and the let-7 family were three of the top 10 down-regulated miRNAs in the metastatic group. Interestingly, these miRNAs have been shown to play anti-metastatic roles in other tumors [194], and target gene analysis of these miRNAs revealed that many of these targets are related to metastasis. For instance, both caspase- 8 and integrin betal are predicted targets of miR-29a and miR-29b, miRNAs known to promote metastasis in breast cancer [195] reviewed in [189]. While the MYCN protein is established as an important regulator of several miRNAs involved in NB tumorigenesis, tumor suppressor miRNAs have also been documented to repress MYCN expression and inhibit cell proliferation of MYCN-amplified NB cells [196]. Several studies published during the last 5 years have implicated MYCN in the regulation of the expression of several miRNAs, many of which have important roles in cancer progression. miRNA induction by MYCN is associated with a widespread repression of coding genes and disease-relevant pathways in NB cells, suggesting that miRNA-controlled regulation of certain groups of miRNAs may function as an additional mechanism of MYCN-induced oncogenicity. 
Indeed, among the targets of MYCN-responsive miRNAs (mir-17/92 cluster, mir-9 and mir-421) there are tumor suppressors and genes involved in the metastatic process. Fontana and co-authors [197] and Schulte and colleagues [198], showed that miRNAs of the miR-17/92 cluster are over-expressed in NB tumors and cell lines with high MYCN expression. Other studies have confirmed direct binding of MYCN to the miR-17-92 promoter [154,199], as well as a positive correlation between expression of MYCN and members of the miR-17/92 cluster in NB primary tumors and/or cell lines [125,126,154,200-202]. On the other hand, miRNAs with tumor suppressor functions (mir-184 and mir-542-5p) have been shown to be inversely correlated to MYCN expression [140,155,193,203]. In fact, miRNA repression seems to be the predominant consequence of MYCN activation, as high MYCN expression is associated with a global repression of miRNAs. Vice versa, miR-34a, miR-101 and let-7 have been documented to target MYCN mRNA, resulting in reduced MYCN expression and decreased proliferation of MYCN-amplified NB cells [196].

Table 3. Biological and clinical relevance of miRNAs in MB.

\begin{tabular}{|c|c|c|c|}
\hline $\begin{array}{l}\text { miRNAs associated with } \\
\text { signaling pathways involved in } \\
\text { MB classification/pathogenesis }\end{array}$ & $\begin{array}{l}\text { miRNAs associated with } \mathrm{MB} \\
\text { and neuronal stem cell biology }\end{array}$ & $\begin{array}{l}\text { miRNAs associated with } \\
\text { metastasis in MB }\end{array}$ & $\begin{array}{l}\text { miRNAs associated with } \\
\text { risk stratification/outcome } \\
\text { prediction }\end{array}$ \\
\hline $\begin{array}{l}\downarrow \mathrm{miR}-125 \mathrm{~b}, \downarrow \mathrm{miR}-326 \text {, and } \\
\downarrow \mathrm{miR}-324-5 \mathrm{p}, \uparrow \mathrm{miR}-214 \text { and } \\
\downarrow \mathrm{miR}-92 \text { (associates with SHH) } \\
{[27]}\end{array}$ & $\begin{array}{l}\text { miR-17/92 (promotes neural stem } \\
\text { cells development, modulating its } \\
\text { cell-fate decision and are also } \\
\text { involved in cancer stem cells and } \\
\text { in MBs biology) [204] }\end{array}$ & $\begin{array}{l}\text { miR-21, miR-182 (promotes } \\
\text { metastasis)miR-182 } \\
\text { contributes to leptomeningeal } \\
\text { metastatic dissemination in } \\
\text { non-SHH-MB [166] }\end{array}$ & $\begin{array}{l}\text { Tumor suppressor miR-31 } \\
\text { and miR-153 } \\
\text { (down-regulated in clinical } \\
\text { high risk MB patients) } \\
{[91,107]}\end{array}$ \\
\hline $\begin{array}{l}\uparrow \mathrm{miR}-183 \sim 96 \sim 182 \text { (associates } \\
\text { with genetic amplification of } \\
\text { MYC in the most clinically } \\
\text { aggressive MB subgroup) } \\
{[119,166]}\end{array}$ & $\begin{array}{l}\text { miR-199b-5p (negatively } \\
\text { regulates MB tumor stem-cell } \\
\text { positive to CD133 antigen) [109] }\end{array}$ & $\begin{array}{l}\text { miR-193a, miR-224/miR-452 } \\
\text { cluster,, and miR-148a } \\
\text { (potential metastasis } \\
\text { suppressive activity) [160] }\end{array}$ & $\begin{array}{l}\text { Oncogene } \\
\text { miR-183 96 182 (highly } \\
\text { expressed in the most } \\
\text { clinically aggressive MB } \\
\text { subgroup) [119] }\end{array}$ \\
\hline $\begin{array}{l}\uparrow \mathrm{miR}-17-92 \text { (correlates with } \\
\mathrm{SHH} \text { as well as c-MYC/MYCN } \\
\text { activation in MB) [162] }\end{array}$ & $\begin{array}{l}\text { miR-125b, miR-324-5p, and } \\
\text { miR-326 (regulate SHH signaling } \\
\text { in cerebellar granule neuron } \\
\text { precursors and MB cells) [27] }\end{array}$ & $\begin{array}{l}\text { miR-199-5p (confreres } \\
\text { inhibition of MB metastasis) } \\
{[109]}\end{array}$ & $\begin{array}{l}\text { Tumor suppressor miR-9 } \\
\text { (downregulation is a } \\
\text { predictive marker for poor } \\
\text { prognosis in } \mathrm{MB} \text { ) [111] }\end{array}$ \\
\hline $\begin{array}{l}\text { miR-10b, } \uparrow \mathrm{miR}-135 \mathrm{a}, \\
\text { miR-135b, } \uparrow \mathrm{miR}-125 \mathrm{~b} \text { and } \\
\downarrow \text { miR-153 (associated with } \\
\text { ErbB2 overexpressing MB } \\
\text { tumors) [91,107] }\end{array}$ & $\begin{array}{l}\text { miR-7, miR-9, and } \downarrow \text { miR-124 } \\
\text { (associated with MB and } \\
\text { Neuronal Differentiation) } \\
{[103,104,111]}\end{array}$ & & $\begin{array}{l}\text { Tumor suppressor } \\
\text { miR-199-5p (low } \\
\text { expression is a predictor for } \\
\text { a poor-risk MB class) [109] }\end{array}$ \\
\hline $\begin{array}{l}\downarrow \mathrm{miR}-181 \mathrm{~b}, \text { miR-128a, and } \\
\downarrow \text { miR-128b (associated with } \\
\text { c-MYC overexpressing MBs) } \\
{[91,107]}\end{array}$ & & & $\begin{array}{l}\text { miR324-5p and miR326 } \\
\text { (promote progressive events } \\
\text { in MBs) [27] }\end{array}$ \\
\hline $\begin{array}{l}\downarrow \mathrm{miR}-199 \mathrm{~b} \text { and } \downarrow \mathrm{miR}-326 \\
\text { miR34a (associated with Notch } \\
\text { Signaling pathway) [109] }\end{array}$ & & & $\begin{array}{l}\text { Tumor suppressor } \\
\text { miR-128b miR-181b low } \\
\text { expression (correlates with } \\
\text { MB disease risk) }[91,107]\end{array}$ \\
\hline
\end{tabular}


Table 3. Cont.

\begin{tabular}{llll}
\hline $\begin{array}{l}\text { miRNAs associated with } \\
\text { signaling pathways involved in }\end{array}$ & $\begin{array}{l}\text { miRNAs associated with MB } \\
\text { and neuronal stem cell biology }\end{array}$ & $\begin{array}{l}\text { miRNAs associated with } \\
\text { metastasis in MB }\end{array}$ & $\begin{array}{l}\text { miRNAs associated with } \\
\text { risk stratification/outcome } \\
\text { prediction }\end{array}$ \\
\hline$\uparrow \mathrm{miR}-193 \mathrm{a}, \uparrow \mathrm{miR}-224 /$ & & \\
$\uparrow \mathrm{miR}-23 \mathrm{~b}, \uparrow \mathrm{miR}-365$ and & & \\
$\uparrow \mathrm{miR}-148 \mathrm{a}$ (over-expressed in & & \\
the WNT signaling associated & & \\
MB) [120,160] & & \\
$\uparrow \mathrm{miR}-\mathrm{let} 7 \mathrm{~g}, \uparrow \mathrm{miR}-19 \mathrm{a}$, & \\
$\uparrow \mathrm{miR}-106 \mathrm{~b}$ and $\uparrow \mathrm{miR}-$ & \\
191distinguish MB differing in & \\
histotypes (anaplastic, classic & \\
and desmoplastic [107] & & \\
\hline
\end{tabular}

$\uparrow$ : Upregulated, $\downarrow$ : Downregulated.

\section{Role of miRNAs as Biomarkers}

With the increasing implication of miRNAs in cancer development and progression, significant efforts are underway to use miRNAs as novel biomarkers with clinical applications [205,206]. miRNA expression is dynamic: many miRNAs are deregulated in early stages of tumor development and up-regulated during cancer progression and could thus be of potential diagnostic utility [207,208]. miRNA expression profiling has been used to characterize embryonal and differentiated tissues of the nervous system [56], to discriminate cancer from normal tissue [97,161] and it can also be used to differentiate primary from metastatic brain tumors [209]. Moreover, miRNAs may be used as biomarkers to identify individuals with increased disease risk, as well as novel prognostic factors [210]. Of note miRNAs can also be detected circulating in several body fluids, including plasma, serum, cerebrospinal fluid, urine and saliva [211-214], reviewed in [215,216]. There are significant differences between the circulating miRNA expression profiles of healthy individuals and those of patients. Consequently, circulating miRNAs are likely to become a novel class of non-invasive and sensitive biomarkers [217]. To be classified as an ideal biomarker, it is crucial that miRNAs show satisfactory predictability and the ability to be inspected during onset, progression and/or regression of the disease. The ease of obtaining and detecting such biomarker from clinical samples is also important. In that regard, circulating miRNAs are particularly promising potential biomarkers in diagnosing diseases because they exhibit an unexpected stability in various body fluids [206,218]. Importantly, obtaining clinical samples that contain circulating miRNAs is a non-invasive and simple process. Moreover, the miRNAs can then easily be detected using quantitative reverse transcription-polymerase chain reaction (qRT-PCR), an efficient and easy to apply technique. These advantages indicate that circulating miRNAs have the potential to be useful candidates for diagnosis and other clinical applications in human diseases. However, because of the small amount of circulating miRNAs, extracting miRNA from body fluids remains technically challenging and needs to be improved. Despite the limitations, the application value of circulating miRNAs in various diseases is gradually being uncovered, reviewed in [217]. In fact the use of circulating microRNAs as potential 
biomarkers is a rapidly evolving field of study [206,219] and the number of recent publications has increased rapidly over the past two years. In the context of CNS diseases, several studies have demonstrated significant presence of certain miRNAs in CSF samples from patients with CNS lymphoma, glioma [214], metastatic brain cancers [213] and Alzheimer's disease [220]. However, the true source of miRNAs in the body fluids and their exact secretory mechanism is relatively unknown [221]. A number of hypotheses have been put forward, such as that circulating miRNAs are present as a result of cell death and lysis or as a result of being actively secreted by cells [222]. The last hypothesis involves either encapsulation of miRNAs into microvesicles such as exosomes [223,224] or alternatively secreted as microvesicle-free (naked) miRNAs [225]. Tumor-derived exosomes containing miRNAs are generally considered pro-tumorigenic. Recent studies have shown that miRNAs contained in tumor-derived exosomes are able to transfer their oncogenic activity to recipient target cells and promote cancer stimulatory activities, such as proliferation, extracellular matrix remodeling, migration, invasion and angiogenesis, and contribute to the pre-metastatic niche formation for the promotion of metastasis, reviewed in [226]. This potential exchange of miRNAs is an exciting and novel dimension to the regulation of a cell's phenotype [227] and is particularly important in cancers that have a propensity for dissemination such as embryonal tumors.

\section{Risk Stratification and Outcome Prediction}

\subsection{Prediction of Clinical Outcome in $M B$}

Risk stratification and prognosis assessment have become a major concern in the era of personalised medicine. Gene expression profiling has reached a plateau in this regard, although recent miRNA studies show great promise [90,119,160] reviewed in [21]. Ferretti et al. identified specific miRNA expression patterns, which distinguish MB differing in histotypes (anaplastic, classic and desmoplastic) and in disease-risk stratification. The authors reported four miRNAs (miR-let7g, miR-19a, miR-106b and miR-191) that are significantly up-regulated in anaplastic versus desmoplastic MBs, miR-let7g and miR-106b were differentially expressed between desmoplastic and classic tumors while only miR-19a was up-regulated in anaplastic versus classic MBs [107]. Importantly their analysis identified both miR-31 and miR-153 as down-regulated in clinical high risk MB patients [91,101,107]. In another study Weeraratne and colleagues reported that increased expression of the miR-183 96 182 cluster of miRNAs has been noted in the most clinically aggressive subgroup and associated with genetic amplification of MYC [119]. Our group recently identified miR-9 as a methylation-silenced tumor suppressor that could be a potential candidate predictive marker for poor prognosis of MB [111]. The investigation demonstrated that LC/A MB samples possess lower miR-9 expression compared to the other variants whereas miR-9 under-expression was associated with poor prognosis in 34 patient samples of MB. The lower overall survival probability of patients with low miR-9 expression that also tends to have a more severe pathological grade suggests a strong trend towards prognostic significance. Moreover, in line with previous reports high expression of the main miR-9 target gene (HES1) correlated significantly with lower overall survival in a distinct cohort of $129 \mathrm{MB}$ samples [167]. Together these data indicate that low expression of miR-9 and the consequently increased expression of its target gene HES1 could be associated with worse MB clinical outcome. In addition, Garzia et al. 
reported that the expression of miR-199-5p (that also targets HES1) is a robust predictor for a poor-risk class and correlates with metastatic spread in patients with MB [109]. In summary, although further verification is required to validate the role of miRNAs in MB risk stratification and outcome prediction, the above mentioned data imply that in the very near future miRNAs may have a wide clinical applicability as potential diagnostic and prognostic biomarkers for MB patients.

\subsection{Prediction of Clinical Outcome in NB}

Several miRNAs have been found to have links with the outcome of NB patients [134,228]. In searching for miRNA target signatures in advanced stage NBs, Guo et al. show that 54 different miRNAs are significantly altered in metastatic as opposed to primary NB tumors [153]. In another study by Pray and colleagues, miR-542-5p over-expression decreases the invasive potential of NB cells [140]. The authors demonstrated that lower expression of miR-542-5p is highly associated with poor patient survival, while ectopic over-expression of this miRNA decreases the invasive potential of NB cell lines in vitro, along with primary tumor growth and metastases in an orthotopic mouse xenograft model. In a parallel study Schulte et al. confirmed that miR-542-5p also discriminated between local and metastatic disease and was inversely correlated with MYCN amplification and event-free survival [155]. Chen et al. identified several miRNAs differentially expressed in different prognostic subtypes of NB. Usually, most of them are down-regulated, as result of MYCN amplification in NB high-risk subgroup. Combined with MYCN amplification, miRNAs down-regulation predicts a poor prognosis in NB patients [193]. In agreement with this trend Creevey et al. determined that miR-497 expression was significantly lower in high-risk MYCN amplified tumors and that low miR-497 expression was associated with worse event-free survival and overall survival in their cohort [229]. The group showed that miR-497 restoration in MYCN amplified NB cells increases NB apoptotic cell death in vitro. Another study showed high expression of MRHG1 was significantly associated with high-risk groups of NB, which was caused by dysregulation of miR-17, miR-18a, miR-19a, miR-20a and miR-92a [117]. The oncogenic activity of miR-18a and miR-19a was proven by Lovén et al. miR-18a and miR-19a have been found to target and repress the expression of estrogen receptor-alpha (ESR1) and high ESR1 expression correlates with increased event-free survival in NB patients and favorable disease outcome [154]. In preclinical studies Tivnan et al. showed that miR-184 significantly reduces tumor growth and increases overall survival in an orthotopic murine model of NB [135]. Others demonstrated that miR-204 increases sensitivity of NB cells to cisplatin and is associated with a favourable clinical outcome [146]. Deep sequencing by Schulte et al. revealed differential expression of miRNAs in favorable versus unfavorable NB. Oncogenic miRNAs of the miR17/92 cluster and the miR-181 family were found to be over-expressed in unfavorable NBs. In contrast, the putative tumor suppressive miR-542-5p and miR-628 were expressed in favorable NBs and virtually absent in unfavorable NBs [125]. Predicting outcome of individual NB patients within risk groups remains challenging and established cytogenetic abnormalities such as MYCN amplification or segmental chromosomal abnormalities do not identify all patients with adverse outcome. Deregulation of miRNAs is associated with the development and progression of NB, hence in the next decade miRNAs are expected to have a significant effect on clinical oncology for the diagnosis and prognosis of NB, and may serve as novel targets for the treatment of high-risk NB patients. 


\section{Pros and Cons of the miRNAs as Biomarkers for Embryonal Neural Tumors}

If the ultimate expectation of miRNAs as biomarkers is to enhance the ability to manage the patient optimally, a key question to ask is whether miRNA biomarkers would significantly improve the diagnostic workup and eventually lead to positive targeted clinical outcome when compared to already in-use diagnostic standards.

Four major risk stratification systems for NB patients are currently being used by combining various clinical, histopathological and molecular markers, such as established cytogenetic abnormalities, mainly chromosomal abnormalities and MYCN amplification. Accordingly, different therapeutic schemes exist ranging from wait-and-see approaches to intensive multimodal therapies. Although the currently used risk stratification systems are considered useful, patients receiving the same treatment can have markedly different clinical courses [230], and established cytogenetic abnormalities do not identify all patients with adverse outcome. On the contrary, molecular-based MB risk stratification is not yet in use in the clinics. Nevertheless a current consensus identifies the existence of four major subgroups of MB, with good prognosis for those with WNT tumors, intermediate prognosis for those with $\mathrm{SHH}$ and Group 4 tumors and poor prognosis for those with Group 3 tumors [87]. However, evidence suggests clinical heterogeneity within these core subgroups [86,167,231] and importantly the putative markers are still waiting to be validated in prospective clinical trials.

Considering the limitations of current cancer conventional biomarkers, the use of miRNAs as tumor markers for diagnosis and prognosis has aroused intense research interests in particular after the outstanding advances in miRNA technologies, such as miRNA microarrays, specific quantitative PCR of miRNA, bead-based miRNA profiling, and antisense technologies. Advanced technologies not only help to identify the oncogenic and tumor suppressor potentials of miRNAs, but also assist in providing a more comprehensive understanding of their underlying mechanisms and pathways. miRNA microarrays can identify the expression of several hundreds miRNAs genes in the same sample at once while requiring only small amounts of total RNA. The widespread and comprehensive use of these high-throughput arrays has enabled the quantification of miRNA expression and the identification of miRNAs uniquely expressed within specific disease [205]. Moreover, profiling of miRNA expression patterns was shown to be more useful than the equivalent mRNA profiles [232]. As such, miRNA expression "signatures" are expected to offer serious potential markers for diagnosing and prognosing cancers of any provenance. However this does not go without restrictions. From clinical sensitivity and specificity point of view although it is suggested that miRNAs would provide increased sensitivity because miRNA profiles have been demonstrated to be pathognomonic, or tissue-specific; however, this does not necessarily translate into disease specificity [233]. The other restrictions that hinder the use of miRNAs as biomarkers include those inherently associated with conventional biomarkers. For example detection and quantification of an ideal marker should be simple, accurate and reproducible. However, miRNA detection currently falls short of most of these requisites. Biological variance, which has been largely neglected, represents an extremely important variable that affect the clinical utility of miRNAs as reliable markers. Currently there are no universally implemented guidelines for specimen collection, preparation and preservation. By using material from different sources obtained with dissimilar techniques, samples are more likely to show wide variability in profile. These are especially 
pronounced when a highly sensitive technique like sequencing is used. Moreover, differences in specimen type can also introduce a profound effect on miRNA concentrations as well as expression levels. In addition to this pre-analytical variability, there are also variables specifically associated with miRNAs extraction and quantification methods. Often there is a low correlation of results obtained from different platforms, and sometimes even within the same platform, using reagents from different vendors. Data normalization, an often underestimated aspect of data processing, is another crucially important concern in obtaining accurate results. Hence baseline parameters such as pre-analytical, intra-individual, and inter-individual variability of miRNAs must be explored and defined. Steps must be taken to carefully select miRNA-profiling platforms and data analysis methods for the acquisition of clinically meaningful and dependable data. Furthermore, standardization of miRNAs extraction assays, quantification methods as well as miRNA biomarker evaluation is definitely needed. Finally and importantly, to date, most of the investigations into the use of miRNAs as biomarkers have been performed mainly in cell lines or animal models while other studies included only small cohorts of patient samples that were not validated in prospective clinical trials. A final decision for human use must be based on results derived from clinical trials with an adequate number of patient samples that represent a proof of concept for the field of miRNA as biomarkers.

\section{9. miRNAs as Potential Cancer Therapeutics}

The rationale for using miRNAs as anticancer drugs is based on the findings that miRNA expression is deregulated in cancer and that cancer phenotype can be changed by targeting miRNA expression. The evidenced deregulation of miRNAs in embryonal tumors [103,104] (Table 1) together with their association with the risk stratification and outcome prediction in these deadly cancers of childhood [103,104] (Tables 2 and 3), recommends miRNAs for targeting as novel therapeutic approaches and as effective treatment tools. Depending on expression levels and function of miRNAs, two approaches to develop miRNA-based therapies can be envisaged: antagonists (inhibition of oncogenic miRNAs) and mimetics (replacement of tumor suppressive miRNAs) [234]. Table 4 illustrates preclinical analysis of diverse aberrantly expressed miRNAs in MB and NB that their therapeutic effects, which were determined with the tactics of reversing the expression level of these miRNAs in vitro and/or in vivo, have proven to be promising, reviewed in [102,235].

Table 4. Example of preclinical functional studies of miRNAs in MB and NB [235].

\begin{tabular}{llll}
\hline microRNAs & Theraputic Potential & Models Investigated & Reference \\
\hline & The adverse prognostic markers in MB (CDK6 SLC16A1D) & D283, D341, D384, \\
& are regulated by miR-124 & D425, D458, \\
$*$ miR124 & Overexpression of the tumor suppressor miR124 decreases MB & ONS-76 MB cell & [88,113] \\
& cell growth in vitro and in xenograft tumors in mice suggesting & lines. D425 xenograft \\
& possible use of miR-124 restoration in MB therapy & tumors in mice. \\
\hline & miR199b-5p target Notch effector HES1, which is involved in & \\
& MB pathogenesis. miR199b-5p overexpression impairs the & Daoy cell line and \\
& $\begin{array}{l}\text { clonogenic potential of MB cell lines. Moreover MB tumor } \\
\text { infection by adenovirus carrying miR199b-5p in a xenograft }\end{array}$ & $\begin{array}{l}\text { Daoy xanograft } \\
\text { mouse model. }\end{array}$ \\
& $\begin{array}{l}\text { model reduces the tumor burden in vivo suggesting possible use } \\
\text { of miR199b-5p as an adjuvant therapy }\end{array}$ & \\
\hline
\end{tabular}


Table 4. Cont.

\begin{tabular}{|c|c|c|c|}
\hline microRNAs & Theraputic Potential & Models Investigated & Reference \\
\hline * miR34a & $\begin{array}{l}\text { miR-34a is a regulator of the Notch ligand Dll1. } \\
\text { Down-regulation of Dll1 expression by miR-34a negatively } \\
\text { regulates cell proliferation, and induces apoptosis and neural } \\
\text { differentiation in MB cells. In addition infection of } \\
\text { adenoviruses carrying the precursor miR-34a induces } \\
\text { neurogenesis, reduces tumor burden, and confers } \\
\text { chemosensitivity in mice xenografts, }\end{array}$ & $\begin{array}{l}\text { Daoy cell line and } \\
\text { Daoy xanograft } \\
\text { mouse model. }\end{array}$ & [236] \\
\hline $\begin{array}{l}* \operatorname{miR} 125 b \\
\operatorname{miR} 324-5 p \\
\operatorname{miR} 326\end{array}$ & $\begin{array}{l}\text { miR125b, miR324-5p, miR326 suppress Hedgehog signaling } \\
\text { which controls cerebellar granule cell progenitor (GCP) } \\
\text { development as well as neoplastic transformation into MB. } \\
\text { Overexpression of these miRNA increases GCP differentiation } \\
\text { and inhibits MB cell proliferation, and colonies formation. }\end{array}$ & $\begin{array}{l}\text { Daoy and D283 cell } \\
\text { lines. }\end{array}$ & [27] \\
\hline * miR128a & $\begin{array}{l}\text { By targeting the Bmi-1 oncogene, miR-128a inhibits growth of } \\
\text { MB cells and alters the intracellular redox state of the tumor } \\
\text { cells and thereby promotes cellular senescence in MB cells. }\end{array}$ & $\begin{array}{l}\text { Daoy, ONS- } 76 \text { cell } \\
\text { lines. }\end{array}$ & [118] \\
\hline * miR383 & $\begin{array}{l}\text { Tumor suppressor miR-383 is down-regulated in MB. } \\
\text { Overexpression of miR383 inhibits MB cell growth through } \\
\text { targeting PRDX3 }\end{array}$ & $\begin{array}{l}\text { Daoy, D283, D341, } \\
\text { D384, D425, D458, } \\
\text { ONS-76 cell lines. }\end{array}$ & [237] \\
\hline $\begin{array}{l}* \text { miR9, } \\
\text { miR125a }\end{array}$ & $\begin{array}{l}\text { miR-9 and miR-125a are tumor suppressors that are } \\
\text { downregulated in MB patient with poor survival. Rescued } \\
\text { expression miR-9 and miR-125a promotes MB cell growth } \\
\text { arrest and apoptosis by targeting truncated TrkC isoform or } \\
\text { notch signal via His1. }\end{array}$ & $\begin{array}{l}\text { D283 and Daoy cell } \\
\text { lines. } \\
\text { D341, D425 }\end{array}$ & {$[107,111]$} \\
\hline * miR218 & $\begin{array}{l}\text { miR-218 is significantly underexpressed in MB. miR- } 218 \text { target } \\
\text { multiple cancer associated genes such as REST, CDK6, } \\
\text { RICTOR and CTSB in MB cells. Re-expression of miR-218 } \\
\text { resultes in a decrease in MB cell growth, colony formation, cell } \\
\text { migration, invasion, and tumor sphere size. }\end{array}$ & $\begin{array}{l}\text { Daoy, D283, D341, } \\
\text { D425, D458 and } \\
\text { UW228 cell lines. }\end{array}$ & {$[238]$} \\
\hline ** miR-17-92 & $\begin{array}{l}\text { Activation of miR-17-92 cluster is known as a marker for poor } \\
\text { prognosis and poor survival of NB. miR-17-92 affect multiple } \\
\text { cancer pathways including DKK3, CDKN1A, BIM, ER- } \alpha \text {, } \\
\text { MEF2D Its activation increases proliferation, decreases } \\
\text { apoptosis and inhibits TGF- } \beta \text { signaling. Aggressive NB evade } \\
\text { the cytostatic TGF } \beta \text {-pathway through miR-17-92 directed } \\
\text { targeting of the pathway. Reactivation of TGF } \beta \text {-signaling } \\
\text { through miR-17-92 inhibition could be a promising therapeutic } \\
\text { approach for NB }\end{array}$ & $\begin{array}{l}\text { SHEP NB cell line } \\
\text { xanograft mouse } \\
\text { model. }\end{array}$ & {$[131]$} \\
\hline$* * \operatorname{miR}-21$ & $\begin{array}{l}\text { Oncogenic miR-21 promotes the proliferation and decreased } \\
\text { sensitivity to chemotherapy of human NB cells. Ectopic } \\
\text { expression of pre-miR- } 21 \text { lower the level of tumor suppressor } \\
\text { PTEN mRNA and protein and in NB cells. Transfection of anti- } \\
\text { miR- } 21 \text { increases the PTEN expression. However, others } \\
\text { reported that inhibition of miR-21 did not affect proliferation of } \\
\text { NB cells, suggesting that the precise biological functions of } \\
\text { miR- } 21 \text { in NB still warrant further studies. }\end{array}$ & $\begin{array}{l}\text { SH-SY5Y and } \\
\text { BE(2)-M17 NB cell } \\
\text { lines }\end{array}$ & [129] \\
\hline
\end{tabular}


Table 4. Cont.

\begin{tabular}{|c|c|c|c|}
\hline microRNAs & Theraputic Potential & Models investigated & Reference \\
\hline ** miR-380-5p & $\begin{array}{l}\text { miR-380 which is highly expressed in NB repress } \mathrm{p} 53- \\
\text { mediated apoptosis, and is associated with poor outcome in NB } \\
\text { with MYCN amplification. miR-380 overexpression cooperates } \\
\text { with activated HRAS oncoprotein and form tumors in mice. } \\
\text { Inhibition of miR-380-5p in embryonic stem or NB cells results } \\
\text { in induction of p53, and apoptotic cell death. In vivo delivery of } \\
\text { a miR-380-5p antagonist decreases tumor size in NB orthotopic } \\
\text { mouse model suggesting a promising potential therapeutic } \\
\text { ability to miR-380 inhibitors }\end{array}$ & $\begin{array}{l}\text { TH-MYCN } \\
\text { transgenic mice of } \\
\text { NB } \\
\text { Orthotopic NB } \\
\text { model }\end{array}$ & [132] \\
\hline ** miR-15a & $\begin{array}{l}\text { miR-15a promotes the migration of NB cells through targeting } \\
\text { the RECK-MMP-9 axis. Suppression of miR-15a decreases the } \\
\text { migration and invasion whereas overexpression increases the } \\
\text { migration ability of NB cell lines. These findings provide } \\
\text { insights into the role of miR-15 in NB migration and invasion } \\
\text { and qualify miR-15a as a potential therapeutic target. }\end{array}$ & $\begin{array}{l}\text { GI-LA-N and SK-N- } \\
\text { SH cell lines }\end{array}$ & [133] \\
\hline$* * \operatorname{miR}-34 a$ & $\begin{array}{l}\text { Tumor suppressive miR-34 family members targets MYCN and } \\
\text { inhibit the growth of NB cell lines In addition, other genes also } \\
\text { targeted by miR-34a, including E2F3, BCL2, CCND1 and } \\
\text { CDK4 were found to be involved in cell proliferation or } \\
\text { apoptosis } \\
\text { Over expression of miR-34a in NB cell lines induces cell cycle } \\
\text { arrest decreases cell number and induces apoptosis. } \\
\text { miR-34a significantly reduces tumor growth in an in vivo } \\
\text { orthotopic murine model. }\end{array}$ & $\begin{array}{l}\text { Kelly, SK-N-AS cell } \\
\text { lines NB1691luc NB } \\
\text { cell lines } \\
\text { NB xanograft mouse } \\
\text { model }\end{array}$ & {$[135]$} \\
\hline
\end{tabular}

* Analysis in MB; ** Analysis in NB. Reviewed in [102,235].

\section{1. miRNA Antagonists}

The most common strategy to ablate miRNA function is achieved by single-stranded oligonucleotides with miRNA complementary sequences (antisense). The backbones of these are chemically modified in order to increase the affinity towards the endogenous miRNA or, alternatively, to trigger the degradation of the endogenous miRNA. Examples of miRNA antagonists are anti-miRNA oligonucleotides (AMOs), locked-nucleic acids (LNA), miRNA sponges, miRNA masking and small molecule inhibitors specific for certain miRNAs [234,239,240]. The most widely used AMO are 2ф-O-methyl AMOs, 2ф-O-methoxyethyl AMOs, and (LNA) AMOs [3,241-244]. miR-21 inhibition in vitro provides a good example of an anti-miR application in cancer cells. Knockdown of miR-21 suppressed cell growth and activated apoptosis in cultured glioblastoma and breast cancer cells [12,161], reduced invasion in metastatic breast cancer, lung metastasis [245], colon cancer [99], glioblastoma [246] and MB culture cells [100].

In vivo studies also showed that treatment with LNA-anti-miR-21 oligonucleotides disrupted glioma growth [247]. Other studies have shown that intravenous administration of AMOs against miR-16, miR-122, miR-192 and miR-194 in animals offer efficient and sustained silencing of corresponding miRNAs [248]. As an alternative to chemically modified antisense oligos, vector-encoded RNA molecules, known as "miRNA sponges" have recently been designed to contain 
multiple tandem binding sites to a miRNA of interest [249-251]. miRNA sponges function by immobilizing the target miRNAs and thus blocking their regulatory function in the cell. miRNA sponges are transcripts under the control of strong promoters (RNA polymerase II) and contain multiple tandem binding sites to a miRNA of interest. miRNA sponges are able to inhibit miRNA function as strongly as AMOs. In addition miRNA sponges have the advantage of being stably integrated into the genome, thus opening up the possibility of creating stable cell lines and transgenic animals that are functionally deficient for a specific miRNA family reviewed in [234,252,253]. However, the risk of insertional mutagenesis in target cells as well as challenges in the delivery of these non-small-molecules makes sponges not ideal for therapeutic applications. "miRNA masking" is another alternative strategy which refers to a sequence with perfect complementarity to the binding site of an endogenous miRNA in the target gene. This "miRNA masking" can form duplex with the target mRNA with higher affinity, therefore blocking the access of endogenous miRNA to its binding site without the potential side effects of mRNA degradation by AMOs [254].

The recent development of small molecules having the ability to modulate the function of miRNAs, renders miRNA pathways susceptible to small molecule inhibitors. Small molecule inhibitors have several advantages over traditional nucleic acid-based tools to manipulate miRNA function, since they are more easily delivered into humans or animals, they are intracellularly more stable, and they are less expensive to manufacture. Based on these promising developments, it can be expected that several new small molecule inhibitors of miRNA function will be discovered in the near future [254].

\section{2. miRNA Replacement Therapy}

miRNA replacement therapy is the strategy of restoring tumor suppressive miRNAs which are lost in cancer cells, to re-establish their "normal" functions. In this regard miRNA mimics are either single or double-stranded miRNA that have the same sequence as the depleted, naturally occurring miRNA. As a consequence, miRNA replacement therapy is expected to have limited off-target effects. The simplicity, specificity and potency of mimicking miRNA precursors have made this an exciting approach to target genes for both research and therapeutic purposes [239].

Several technologies have proven effective in delivering therapeutic miRNAs to tumor tissues in vivo. These include adenoviral or lentiviral vector-based systems that were originally developed for gene therapy. A viral approach has been used to reintroduce Let-7 expression in an orthotopic lung cancer mouse model [255]. The reintroduction of Let-7 significantly reduced lung tumor formation in vivo [256]. In line with this is the reintroduction of miR-26a in a liver cancer mouse model, which resulted in the inhibition of cancer cell proliferation, induction of tumor-specific apoptosis, and prevention of disease progression [257]. Another example that shows the value of miRNA replacement is provided by miR-34a [258]. In this case, therapeutic delivery of miR-34a led to an accumulation of miR-34a in the tumor tissue, suppression of known miR-34a target genes and, most importantly, inhibition of lung tumor growth [240]. Similar to the replacement therapy approach but differing in miRNA delivery, unmodified miR-145 and miR-33a have been delivered by using polyethylenimine (PEI) in a mouse model of colon carcinoma, a method that proved efficacious [259]. Likewise transient transfection with synthetic miR-16 significantly reduced cell proliferation in prostate cancer cells in vitro and reduced metastasis in vivo [260]. Another example of the success of miRNA 
replacement therapy is demonstrated by Garzia et al. [109]. The group showed that MB tumor burden can be reduced in a xenograft model by miR-199-5p overexpression, indicating the therapeutic potential of miR199b-5p. Also replacement for miR-15 and miR-16 [261], that are often deleted in CLL patients [261-263], reduces proliferation and triggers leukemic cell death, reviewed in [264].

Together, the evidence showing that miRNAs can function as tumor suppressors, and that the synthetic versions of these miRNAs robustly interfere with tumor growth, reflects the importance of miRNAs in cancer and strongly supports the development of miRNA mimics as ideal candidates for therapeutic intervention.

\subsection{Challenges of miRNA-based Therapies}

miRNAs biological instability, the difficulties of specific delivery, and the insufficient uptake for effective target inhibition challenge the development of miRNA-based therapies. To overcome these obstacles chemical modifications in oligonucleotides have been investigated, however the drawbacks of improved delivery to tissues after chemical modifications are impaired biological activity and increased toxicity. To solve these problems, novel miRNA formulations, including nanoparticles, polymers or viral transduction approaches, are currently under development. Moreover, effort is put into the engineering of effective systems that deliver synthetic miRNAs selectively to diseased tissues in order to limit potentially toxic off-target effects, reviewed in [265]. Finally and importantly homeostasis of the brain is dependent on the blood-brain barrier (BBB) that dictates the exchange of essential nutrients and limits the entrance of molecules and immune cells into the central nervous system. This barrier therefore forms yet another important hurdle for effective miRNAs treatment of malignant brain cancer. Hence effective brain delivery for miRNAs may require the design of particular therapeutic approaches that overcome this physiological obstruction, such as the use of nanoparticles, immunoliposomes, peptide vectors or carrier-mediated transport through the BBB, reviewed in [266].

In summary, the recent fast progress in the field has triggered some optimism about the development of successful molecules targeting microRNAs. However miRNAs targeting approaches are still at the preclinical stage and even with promising preclinical responses to molecules targeting miRNAs or their target genes, it is expected that tumor types and context will add to the complexity and heterogeneity of response to any of the above mentioned strategies. New therapies targeting miRNAs or its' target genes may best be applied in the future together with molecular profiling of cancers for clinical stratification and selection of combination therapies.

\section{Concluding Remarks}

Within the last decade, substantial progress has been made in understanding embryonal tumor development through the discovery of deregulations in the highly conserved developmental signaling pathways. However, effective targeted therapies still remain elusive and the development of novel therapeutic strategies remains an urgent goal. Risk stratification and drug-response prediction are the central elements of targeted therapies. During recent years, research has focused mainly on gene expression profiling in embryonal tumors and a number of important studies have been published. As gene expression profiling reaches a plateau and begins to face limitations, miRNA signature is a rising 
star that may provide new resolutions to old problems. Numerous miRNAs are dysregulated in pediatric cancers, and evidence suggests miRNAs as attractive targets in cancer therapy. A greater understanding of miRNA biology and the development of suitable delivery systems are required to translate basic research results into clinical practice. miRNAs are much more stable in body fluids than mRNAs, raising the exciting prospect that miRNAs might be used as non-invasive biomarkers for disease monitoring and risk stratification under specific circumstances. Insights gained from miRNA studies may open a new era in pediatric brain cancer treatments which provides improved patient selection for targeted agents, and forms the basis for the development of novel therapeutics and/or early disease biomarkers.

\section{Acknowledgements}

We thank Nicola Shalaby for the manuscript proofreading. This project was supported by the Swiss Research Foundation Child and Cancer and by Krebsliga Zürich.

\section{Author Contributions}

Tarek Shalaby: Acquisition, interpretation of data and wrote the manuscript; Giulio Fiaschetti: References management. Revising the review critically for important intellectual content; Martin Baumgartner: Revising the review critically for important intellectual content; Michael A. Grotzer: Contributed to conception and design of the review.

\section{Conflicts of Interest}

The authors declare no conflict of interest.

\section{References}

1. Shalaby, T.; Hiyama, E.; Grotzer, M.A. Telomere maintenance as therapeutic target in embryonal tumours. Anticancer Agents Med. Chem. 2010, 10, 196-212.

2. Grimmer, M.R.; Weiss, W.A. Childhood tumors of the nervous system as disorders of normal development. Curr. Opin. Pediatr. 2006, 18, 634-638.

3. Wu, W. Modulation of microRNAs for potential cancer therapeutics. Methods Mol. Biol. 2011, 676, 59-70.

4. Hatfield, S.D.; Shcherbata, H.R.; Fischer, K.A.; Nakahara, K.; Carthew, R.W.; Ruohola-Baker, H. Stem cell division is regulated by the microRNA pathway. Nature $\mathbf{2 0 0 5}, 435,974-978$.

5. Jin, Z.; Xie, T. Dcr-1 maintains Drosophila ovarian stem cells. Curr. Biol. 2007, 17, 539-544.

6. Kanellopoulou, C.; Muljo, S.A.; Kung, A.L.; Ganesan, S.; Drapkin, R.; Jenuwein, T.; Livingston, D.M.; Rajewsky, K. Dicer-deficient mouse embryonic stem cells are defective in differentiation and centromeric silencing. Genes Dev. 2005, 19, 489-501.

7. Murchison, E.P.; Partridge, J.F.; Tam, O.H.; Cheloufi, S.; Hannon, G.J. Characterization of Dicerdeficient murine embryonic stem cells. Proc. Natl. Acad. Sci. USA 2005, 102, 12135-12140.

8. Park, J.K.; Liu, X.; Strauss, T.J.; McKearin, D.M.; Liu, Q. The miRNA pathway intrinsically controls self-renewal of Drosophila germline stem cells. Curr. Biol. 2007, 17, 533-538. 
9. Tran, N.; McLean, T.; Zhang, X.; Zhao, C.J.; Thomson, J.M.; O’Brien, C.; Rose, B. MicroRNA expression profiles in head and neck cancer cell lines. Biochem. Biophys. Res. Commun. 2007, $358,12-17$.

10. Calin, G.A.; Croce, C.M. Chronic lymphocytic leukemia: Interplay between noncoding RNAs and protein-coding genes. Blood 2009, 114, 4761-4770.

11. He, H.; Jazdzewski, K.; Li, W.; Liyanarachchi, S.; Nagy, R.; Volinia, S.; Calin, G.A.; Liu, C.G.; Franssila, K.; Suster, S.; et al. The role of microRNA genes in papillary thyroid carcinoma. Proc. Natl. Acad. Sci. USA 2005, 102, 19075-19080.

12. Si, M.L.; Zhu, S.; Wu, H.; Lu, Z.; Wu, F.; Mo, Y.Y. miR-21-mediated tumor growth. Oncogene 2007, 26, 2799-2803.

13. Corcoran, C.; Friel, A.M.; Duffy, M.J.; Crown, J.; O’Driscoll, L. Intracellular and extracellular microRNAs in breast cancer. Clin. Chem. 2011, 57, 18-32.

14. Zhu, R.; Ji, Y.; Xiao, L.; Matin, A. Testicular germ cell tumor susceptibility genes from the consomic 129.MOLF-Chr19 mouse strain. Mamm. Genome 2007, 18, 584-595.

15. Voorhoeve, P.M.; le Sage, C.; Schrier, M.; Gillis, A.J.; Stoop, H.; Nagel, R.; Liu, Y.P.; van Duijse, J.; Drost, J.; Griekspoor, A.; et al. A genetic screen implicates miRNA-372 and miRNA-373 as oncogenes in testicular germ cell tumors. Cell 2006, 124, 1169-1181.

16. King, C.E.; Wang, L.; Winograd, R.; Madison, B.B.; Mongroo, P.S.; Johnstone, C.N.; Rustgi, A.K. LIN28B fosters colon cancer migration, invasion and transformation through let-7-dependent and -independent mechanisms. Oncogene 2011, 30, 4185-4193.

17. De Krijger, I.; Mekenkamp, L.J.; Punt, C.J.; Nagtegaal, I.D. MicroRNAs in colorectal cancer metastasis. J. Pathol. 2011, 224, 438-447.

18. Murray, M.Y.; Rushworth, S.A.; Macewan, D.J. MicroRNAs as a new therapeutic target towards leukaemia signalling. Cell. Signal. 2012, 24, 363-368.

19. Lv, M.; Zhang, X.; Jia, H.; Li, D.; Zhang, B.; Zhang, H.; Hong, M.; Jiang, T.; Jiang, Q.; Lu, J.; et al. An oncogenic role of miR-142-3p in human T-cell acute lymphoblastic leukemia (T-ALL) by targeting glucocorticoid receptor-alpha and cAMP/PKA pathways. Leukemia 2012, 26, 769-777.

20. Zhu, W.; Liu, X.; He, J.; Chen, D.; Hunag, Y.; Zhang, Y.K. Overexpression of members of the microRNA-183 family is a risk factor for lung cancer: A case control study. BMC Cancer 2011, 11, 393, doi:10.1186/1471-2407-11-393.

21. Lin, P.Y.; Yu, S.L.; Yang, P.C. MicroRNA in lung cancer. Br. J. Cancer 2010, 103, 1144-1148.

22. Yu, F.; Yao, H.; Zhu, P.; Zhang, X.; Pan, Q.; Gong, C.; Huang, Y.; Hu, X.; Su, F.; Lieberman, J.; et al. let-7 regulates self renewal and tumorigenicity of breast cancer cells. Cell 2007, 131, 1109-1123.

23. Hatfield, S.; Ruohola-Baker, H. microRNA and stem cell function. Cell Tissue Res. 2008, 331, 57-66.

24. Croce, C.M.; Calin, G.A. miRNAs, cancer, and stem cell division. Cell 2005, 122, 6-7.

25. Silber, J.; Lim, D.A.; Petritsch, C.; Persson, A.I.; Maunakea, A.K.; Yu, M.; Vandenberg, S.R.; Ginzinger, D.G.; James, C.D.; Costello, J.F.; et al. miR-124 and miR-137 inhibit proliferation of glioblastoma multiforme cells and induce differentiation of brain tumor stem cells. BMC Med. 2008, 6, 14, doi:10.1186/1741-7015-6-14. 
26. DeSano, J.T.; Xu, L. MicroRNA regulation of cancer stem cells and therapeutic implications. AAPS J. 2009, 11, 682-692.

27. Ferretti, E.; de Smaele, E.; Miele, E.; Laneve, P.; Po, A.; Pelloni, M.; Paganelli, A.; di Marcotullio, L.; Caffarelli, E.; Screpanti, I.; et al. Concerted microRNA control of Hedgehog signalling in cerebellar neuronal progenitor and tumour cells. EMBO J. 2008, 27, 2616-2627.

28. Legler, J.M.; Ries, L.A.; Smith, M.A.; Warren, J.L.; Heineman, E.F.; Kaplan, R.S.; Linet, M.S. Cancer surveillance series [corrected]: Brain and other central nervous system cancers: Recent trends in incidence and mortality. J. Natl. Cancer Inst. 1999, 91, 1382-1390.

29. Louis, D.N.; Ohgaki, H.; Wiestler, O.D.; Cavenee, W.K.; Burger, P.C.; Jouvet, A.; Scheithauer, B.W.; Kleihues, P. The 2007 WHO Classification of Tumours of the Central Nervous System. Acta Neuropathol. (Berl.) 2007, 114, 97-109.

30. Bartel, D.P. MicroRNAs: Genomics, biogenesis, mechanism, and function. Cell 2004, 116, 281-297.

31. Calin, G.A.; Sevignani, C.; Dumitru, C.D.; Hyslop, T.; Noch, E.; Yendamuri, S.; Shimizu, M.; Rattan, S.; Bullrich, F.; Negrini, M.; et al. Human microRNA genes are frequently located at fragile sites and genomic regions involved in cancers. Proc. Natl. Acad. Sci. USA 2004, 101, 2999-3004.

32. Palmero, E.I.; de Campos, S.G.; Campos, M.; de Souza, N.C.; Guerreiro, I.D.; Carvalho, A.L.; Marques, M.M. Mechanisms and role of microRNA deregulation in cancer onset and progression. Genet. Mol. Biol. 2011, 34, 363-370.

33. Esquela-Kerscher, A.; Slack, F.J. Oncomirs-microRNAs with a role in cancer. Nat. Rev. Cancer 2006, 6, 259-269.

34. Calin, G.A.; Croce, C.M. MicroRNA signatures in human cancers. Nat. Rev. Cancer 2006, 6, 857-866.

35. Medina, P.P.; Slack, F.J. microRNAs and cancer: An overview. Cell Cycle 2008, 7, 2485-2492.

36. Croce, C.M. Causes and consequences of microRNA dysregulation in cancer. Nat. Rev. Genet. 2009, 10, 704-714.

37. Navarro, A.; Monzo, M. MicroRNAs in human embryonic and cancer stem cells. Yonsei Med. J. 2010, 51, 622-632.

38. Zhao, B.; Huang, B.; Li, W.; Jin, Y. MicroRNA expression profiling during neural differentiation of mouse embryonic carcinoma P19 cells. Methods Mol. Biol. 2013, 936, 105-116.

39. Lakshmipathy, U.; Davila, J.; Hart, R.P. miRNA in pluripotent stem cells. Regen. Med. 2010, 5, 545-555.

40. Yekta, S.; Shih, I.H.; Bartel, D.P. MicroRNA-directed cleavage of HOXB8 mRNA. Science 2004, 304, 594-596.

41. Visvanathan, J.; Lee, S.; Lee, B.; Lee, J.W.; Lee, S.K. The microRNA miR-124 antagonizes the anti-neural REST/SCP1 pathway during embryonic CNS development. Genes Dev. 2007, 21, 744-749.

42. Suh, M.R.; Lee, Y.; Kim, J.Y.; Kim, S.K.; Moon, S.H.; Lee, J.Y.; Cha, K.Y.; Chung, H.M.; Yoon, H.S.; Moon, S.Y.; et al. Human embryonic stem cells express a unique set of microRNAs. Dev. Biol. 2004, 270, 488-498.

43. Slack, F.J. Stem cells: Big roles for small RNAs. Nature 2010, 463, 616, doi:10.1038/463616a. 
44. Makeyev, E.V.; Zhang, J.; Carrasco, M.A.; Maniatis, T. The MicroRNA miR-124 promotes neuronal differentiation by triggering brain-specific alternative pre-mRNA splicing. Mol. Cell 2007, 27, 435-448.

45. Houbaviy, H.B.; Murray, M.F.; Sharp, P.A. Embryonic stem cell-specific MicroRNAs. Dev. Cell 2003, 5, 351-358.

46. Cao, X.; Yeo, G.; Muotri, A.R.; Kuwabara, T.; Gage, F.H. Noncoding RNAs in the mammalian central nervous system. Annu. Rev. Neurosci. 2006, 29, 77-103.

47. Cao, X.; Pfaff, S.L.; Gage, F.H. A functional study of miR-124 in the developing neural tube. Genes Dev. 2007, 21, 531-536.

48. Viswanathan, S.R.; Daley, G.Q.; Gregory, R.I. Selective blockade of microRNA processing by Lin28. Science 2008, 320, 97-100.

49. Morin, R.D.; O’Connor, M.D.; Griffith, M.; Kuchenbauer, F.; Delaney, A.; Prabhu, A.L.; Zhao, Y.; McDonald, H.; Zeng, T.; Hirst, M.; et al. Application of massively parallel sequencing to microRNA profiling and discovery in human embryonic stem cells. Genome Res. 2008, 18, 610-621.

50. Mineno, J.; Okamoto, S.; Ando, T.; Sato, M.; Chono, H.; Izu, H.; Takayama, M.; Asada, K.; Mirochnitchenko, O.; Inouye, M.; et al. The expression profile of microRNAs in mouse embryos. Nucleic Acids Res. 2006, 34, 1765-1771.

51. Lee, C.T.; Risom, T.; Strauss, W.M. MicroRNAs in mammalian development. Birth Defects Res. C Embryo Today 2006, 78, 129-139.

52. Goff, L.A.; Davila, J.; Swerdel, M.R.; Moore, J.C.; Cohen, R.I.; Wu, H.; Sun, Y.E.; Hart, R.P. Ago2 immunoprecipitation identifies predicted microRNAs in human embryonic stem cells and neural precursors. PLoS One 2009, 4, e7192.

53. Gangaraju, V.K.; Lin, H. MicroRNAs: Key regulators of stem cells. Nat. Rev. Mol. Cell Biol. 2009, 10, 116-125.

54. Bar, M.; Wyman, S.K.; Fritz, B.R.; Qi, J.; Garg, K.S.; Parkin, R.K.; Kroh, E.M.; Bendoraite, A.; Mitchell, P.S.; Nelson, A.M.; et al. MicroRNA discovery and profiling in human embryonic stem cells by deep sequencing of small RNA libraries. Stem Cells 2008, 26, 2496-2505.

55. Coolen, M.; Bally-Cuif, L. MicroRNAs in brain development and physiology. Curr. Opin. Neurobiol. 2009, 19, 461-470.

56. Kapsimali, M.; Kloosterman, W.P.; de Bruijn, E.; Rosa, F.; Plasterk, R.H.; Wilson, S.W. MicroRNAs show a wide diversity of expression profiles in the developing and mature central nervous system. Genome Biol. 2007, 8, R173, doi:10.1186/gb-2007-8-8-r173.

57. Giraldez, A.J.; Cinalli, R.M.; Glasner, M.E.; Enright, A.J.; Thomson, J.M.; Baskerville, S.; Hammond, S.M.; Bartel, D.P.; Schier, A.F. MicroRNAs regulate brain morphogenesis in zebrafish. Science 2005, 308, 833-838.

58. Zhao, C.; Sun, G.; Li, S.; Shi, Y. A feedback regulatory loop involving microRNA-9 and nuclear receptor TLX in neural stem cell fate determination. Nat. Struct. Mol. Biol. 2009, 16, 365-371.

59. Yu, J.Y.; Chung, K.H.; Deo, M.; Thompson, R.C.; Turner, D.L. MicroRNA miR-124 regulates neurite outgrowth during neuronal differentiation. Exp. Cell Res. 2008, 314, 2618-2633.

60. Sempere, L.F.; Freemantle, S.; Pitha-Rowe, I.; Moss, E.; Dmitrovsky, E.; Ambros, V. Expression profiling of mammalian microRNAs uncovers a subset of brain-expressed microRNAs with 
possible roles in murine and human neuronal differentiation. Genome Biol. 2004, 5, R13, doi:10.1186/gb-2004-5-3-r13.

61. Packer, A.N.; Xing, Y.; Harper, S.Q.; Jones, L.; Davidson, B.L. The bifunctional microRNA miR-9/miR-9* regulates REST and CoREST and is downregulated in Huntington's disease. J. Neurosci. 2008, 28, 14341-14346.

62. Miska, E.A.; Alvarez-Saavedra, E.; Townsend, M.; Yoshii, A.; Sestan, N.; Rakic, P.; Constantine-Paton, M.; Horvitz, H.R. Microarray analysis of microRNA expression in the developing mammalian brain. Genome Biol. 2004, 5, R68, doi:10.1186/gb-2004-5-9-r68.

63. Landgraf, P.; Rusu, M.; Sheridan, R.; Sewer, A.; Iovino, N.; Aravin, A.; Pfeffer, S.; Rice, A.; Kamphorst, A.O.; Landthaler, M.; et al. A mammalian microRNA expression atlas based on small RNA library sequencing. Cell 2007, 129, 1401-1414.

64. Kim, J.; Inoue, K.; Ishii, J.; Vanti, W.B.; Voronov, S.V.; Murchison, E.; Hannon, G.; Abeliovich, A. A MicroRNA feedback circuit in midbrain dopamine neurons. Science 2007, 317, 1220-1224.

65. Conaco, C.; Otto, S.; Han, J.J.; Mandel, G. Reciprocal actions of REST and a microRNA promote neuronal identity. Proc. Natl. Acad. Sci. USA 2006, 103, 2422-2427.

66. Choi, P.S.; Zakhary, L.; Choi, W.Y.; Caron, S.; Alvarez-Saavedra, E.; Miska, E.A.; McManus, M.; Harfe, B.; Giraldez, A.J.; Horvitz, H.R.; et al. Members of the miRNA-200 family regulate olfactory neurogenesis. Neuron 2008, 57, 41-55.

67. Cheng, L.C.; Pastrana, E.; Tavazoie, M.; Doetsch, F. miR-124 regulates adult neurogenesis in the subventricular zone stem cell niche. Nat. Neurosci. 2009, 12, 399-408.

68. Kim, J.; Krichevsky, A.; Grad, Y.; Hayes, G.D.; Kosik, K.S.; Church, G.M.; Ruvkun, G. Identification of many microRNAs that copurify with polyribosomes in mammalian neurons. Proc. Natl. Acad. Sci. USA 2004, 101, 360-365.

69. Fernandez, L.A.; Northcott, P.A.; Taylor, M.D.; Kenney, A.M. Normal and oncogenic roles for microRNAs in the developing brain. Cell Cycle 2009, 8, 4049-4054.

70. Zhao, C.; Deng, W.; Gage, F.H. Mechanisms and functional implications of adult neurogenesis. Cell 2008, 132, 645-660.

71. Lin, S.L.; Chang, D.C.; Chang-Lin, S.; Lin, C.H.; Wu, D.T.; Chen, D.T.; Ying, S.Y. Mir-302 reprograms human skin cancer cells into a pluripotent ES-cell-like state. RNA 2008, 14, 2115-2124.

72. Singh, S.K.; Hawkins, C.; Clarke, I.D.; Squire, J.A.; Bayani, J.; Hide, T.; Henkelman, R.M.; Cusimano, M.D.; Dirks, P.B. Identification of human brain tumour initiating cells. Nature 2004, 432, 396-401.

73. Singh, S.K.; Clarke, I.D.; Terasaki, M.; Bonn, V.E.; Hawkins, C.; Squire, J.; Dirks, P.B. Identification of a cancer stem cell in human brain tumors. Cancer Res. 2003, 63, 5821-5828.

74. Yang, Z.J.; Ellis, T.; Markant, S.L.; Read, T.A.; Kessler, J.D.; Bourboulas, M.; Schuller, U.; Machold, R.; Fishell, G.; Rowitch, D.H.; et al. Medulloblastoma can be initiated by deletion of Patched in lineage-restricted progenitors or stem cells. Cancer Cell 2008, 14, 135-145.

75. Fan, X.; Eberhart, C.G. Medulloblastoma stem cells. J. Clin. Oncol. 2008, 26, 2821-2827.

76. Mantamadiotis, T.; Taraviras, S. Self-renewal mechanisms in neural cancer stem cells. Front. Biosci. 2011, 16, 598-607. 
77. Gurney, J.G.; Smith, M.A.; Bunin, G.R. CNS and miscellaneous intracranial and intraspinal neoplasms. In Cancer Incidence and Survival among Children and Adolescents: United States SEER Program, 1975-1995; Ries, L.A.G., Smith, M.A., Gurney, J.G., Linet, M., Tamra, T., Young, J.L., Bunin, G.R., Eds.; National Institutes of Health: Bethesda, MD, USA, 1999; pp. 51-63.

78. Giangaspero, F.; Perilongo, G.; Fondelli, M.P.; Brisigotti, M.; Carollo, C.; Burnelli, R.; Burger, P.C.; Garre, M.L. Medulloblastoma with extensive nodularity: A variant with favorable prognosis. J. Neurosurg. 1999, 91, 971-977.

79. McManamy, C.S.; Pears, J.; Weston, C.L.; Hanzely, Z.; Ironside, J.W.; Taylor, R.E.; Grundy, R.G.; Clifford, S.C.; Ellison, D.W. Nodule formation and desmoplasia in medulloblastomas-defining the nodular/desmoplastic variant and its biological behavior. Brain Pathol. 2007, 17, 151-164.

80. Pfister, S.; Remke, M.; Benner, A.; Mendrzyk, F.; Toedt, G.; Felsberg, J.; Wittmann, A.; Devens, F.; Gerber, N.U.; Joos, S.; et al. Outcome prediction in pediatric medulloblastoma based on DNA copy-number aberrations of chromosomes $6 \mathrm{q}$ and $17 \mathrm{q}$ and the MYC and MYCN loci. J. Clin. Oncol. 2009, 27, 1627-1636.

81. Thompson, M.C.; Fuller, C.; Hogg, T.L.; Dalton, J.; Finkelstein, D.; Lau, C.C.; Chintagumpala, M.; Adesina, A.; Ashley, D.M.; Kellie, S.J.; et al. Genomics identifies medulloblastoma subgroups that are enriched for specific genetic alterations. J. Clin. Oncol. 2006, 24, 1924-1931.

82. Kool, M.; Koster, J.; Bunt, J.; Hasselt, N.E.; Lakeman, A.; van Sluis, P.; Troost, D.; Meeteren, N.S.; Caron, H.N.; Cloos, J.; et al. Integrated genomics identifies five medulloblastoma subtypes with distinct genetic profiles, pathway signatures and clinicopathological features. PLoS One 2008, 3, e3088.

83. Pfister, S.M.; Korshunov, A.; Kool, M.; Hasselblatt, M.; Eberhart, C.; Taylor, M.D. Molecular diagnostics of CNS embryonal tumors. Acta Neuropathol. 2010, 120, 553-566.

84. Northcott, P.A.; Korshunov, A.; Witt, H.; Hielscher, T.; Eberhart, C.G.; Mack, S.; Bouffet, E.; Clifford, S.C.; Hawkins, C.E.; French, P.; et al. Medulloblastoma comprises four distinct molecular variants. J. Clin. Oncol. 2011, 29, 1408-1414.

85. Kool, M.; Korshunov, A.; Remke, M.; Jones, D.T.; Schlanstein, M.; Northcott, P.A.; Cho, Y.J.; Koster, J.; Schouten-van Meeteren, A.; van Vuurden, D.; et al. Molecular subgroups of medulloblastoma: An international meta-analysis of transcriptome, genetic aberrations, and clinical data of WNT, SHH, Group 3, and Group 4 medulloblastomas. Acta Neuropathol. 2012, 123, 473-484.

86. Remke, M.; Hielscher, T.; Korshunov, A.; Northcott, P.A.; Bender, S.; Kool, M.; Westermann, F.; Benner, A.; Cin, H.; Ryzhova, M.; et al. FSTL5 is a marker of poor prognosis in non-WNT/ non-SHH medulloblastoma. J. Clin. Oncol. 2011, 29, 3852-3861.

87. Taylor, M.D.; Northcott, P.A.; Korshunov, A.; Remke, M.; Cho, Y.J.; Clifford, S.C.; Eberhart, C.G.; Parsons, D.W.; Rutkowski, S.; Gajjar, A.; et al. Molecular subgroups of medulloblastoma: The current consensus. Acta Neuropathol. 2012, 123, 465-472.

88. Pierson, J.; Hostager, B.; Fan, R.; Vibhakar, R. Regulation of cyclin dependent kinase 6 by microRNA 124 in medulloblastoma. J. Neuro-Oncol. 2008, 90, 1-7. 
89. Mendrzyk, F.; Radlwimmer, B.; Joos, S.; Kokocinski, F.; Benner, A.; Stange, D.E.; Neben, K.; Fiegler, H.; Carter, N.P.; Reifenberger, G.; et al. Genomic and protein expression profiling identifies CDK6 as novel independent prognostic marker in medulloblastoma. J. Clin. Oncol. 2005, 23, 8853-8862.

90. Northcott, P.A.; Fernandez, L.A.; Hagan, J.P.; Ellison, D.W.; Grajkowska, W.; Gillespie, Y.; Grundy, R.; van Meter, T.; Rutka, J.T.; Croce, C.M.; et al. The miR-17/92 polycistron is up-regulated in sonic hedgehog-driven medulloblastomas and induced by N-myc in sonic hedgehog-treated cerebellar neural precursors. Cancer Res. 2009, 69, 3249-3255.

91. Pang, J.C.; Kwok, W.K.; Chen, Z.; Ng, H.K. Oncogenic role of microRNAs in brain tumors. Acta Neuropathol. 2009, 117, 599-611.

92. Ciafre, S.A.; Galardi, S.; Mangiola, A.; Ferracin, M.; Liu, C.G.; Sabatino, G.; Negrini, M.; Maira, G.; Croce, C.M.; Farace, M.G. Extensive modulation of a set of microRNAs in primary glioblastoma. Biochem. Biophys. Res. Commun. 2005, 334, 1351-1358.

93. Turner, J.D.; Williamson, R.; Almefty, K.K.; Nakaji, P.; Porter, R.; Tse, V.; Kalani, M.Y. The many roles of microRNAs in brain tumor biology. Neurosurg. Focus 2010, 28, E3, doi:10.3171/2009.10.FOCUS09207.

94. Laneve, P.; Di Marcotullio, L.; Gioia, U.; Fiori, M.E.; Ferretti, E.; Gulino, A.; Bozzoni, I.; Caffarelli, E. The interplay between microRNAs and the neurotrophin receptor tropomyosin-related kinase C controls proliferation of human neuroblastoma cells. Proc. Natl. Acad. Sci. USA 2007, 104, 7957-7962.

95. Birks, D.K.; Barton, V.N.; Donson, A.M.; Handler, M.H.; Vibhakar, R.; Foreman, N.K. Survey of MicroRNA expression in pediatric brain tumors. Pediatr. Blood Cancer 2011, 56, 211-216.

96. Ma, L.; Weinberg, R.A. Micromanagers of malignancy: Role of microRNAs in regulating metastasis. Trends Genet. 2008, 24, 448-456.

97. Ventura, A.; Jacks, T. MicroRNAs and cancer: Short RNAs go a long way. Cell 2009, 136, $586-591$.

98. White, N.M.; Fatoohi, E.; Metias, M.; Jung, K.; Stephan, C.; Yousef, G.M. Metastamirs: A stepping stone towards improved cancer management. Nat. Rev. Clin. Oncol. 2011, 8, 75-84.

99. Asangani, I.A.; Rasheed, S.A.; Nikolova, D.A.; Leupold, J.H.; Colburn, N.H.; Post, S.; Allgayer, H. MicroRNA-21 (miR-21) post-transcriptionally downregulates tumor suppressor Pdcd4 and stimulates invasion, intravasation and metastasis in colorectal cancer. Oncogene 2008, 27, 2128-2136.

100. Grunder, E.; D’Ambrosio, R.; Fiaschetti, G.; Abela, L.; Arcaro, A.; Zuzak, T.; Ohgaki, H.; Lv, S.Q.; Shalaby, T.; Grotzer, M. MicroRNA-21 suppression impedes medulloblastoma cell migration. Eur. J. Cancer 2011, 47, 2479-2490.

101. Ajeawung, N.F.; Li, B.; Kamnasaran, D. Translational applications of microRNA genes in medulloblastomas. Clin. Investig. Med. 2010, 33, E223-E233.

102. Mei, H.; Lin, Z.Y.; Tong, Q.S. The roles of microRNAs in neuroblastoma. World J. Pediatr. 2014, 10, 10-16.

103. Spence, T.N.J.; Bouffet, E.; Huang, A.; Cho, W.C.S. MicroRNAs in Brain Tumors; Springer Netherlands: Dordrecht, The Netherlands, 2011. 
104. Zollo, M.; Andolfo, I.; de Antonellis, P. MicroRNAs and Cancer Stem Cells in Medulloblastoma; Shostak, S., Ed.; InTech: Rijeka, Croatia, 2011.

105. Dews, M.; Homayouni, A.; Yu, D.; Murphy, D.; Sevignani, C.; Wentzel, E.; Furth, E.E.; Lee, W.M.; Enders, G.H.; Mendell, J.T.; et al. Augmentation of tumor angiogenesis by a Myc-activated microRNA cluster. Nat. Genet. 2006, 38, 1060-1065.

106. Mavrakis, K.J.; Wolfe, A.L.; Oricchio, E.; Palomero, T.; de Keersmaecker, K.; McJunkin, K.; Zuber, J.; James, T.; Khan, A.A.; Leslie, C.S.; et al. Genome-wide RNA-mediated interference screen identifies miR-19 targets in Notch-induced T-cell acute lymphoblastic leukaemia. Nat. Cell Biol. 2010, 12, 372-379.

107. Ferretti, E.; de Smaele, E.; Po, A.; di Marcotullio, L.; Tosi, E.; Espinola, M.S.; di Rocco, C.; Riccardi, R.; Giangaspero, F.; Farcomeni, A.; et al. MicroRNA profiling in human medulloblastoma. Int. J. Cancer 2009, 124, 568-577.

108. Roush, S.; Slack, F.J. The let-7 family of microRNAs. Trends Cell Biol. 2008, 18, 505-516.

109. Garzia, L.; Andolfo, I.; Cusanelli, E.; Marino, N.; Petrosino, G.; de Martino, D.; Esposito, V.; Galeone, A.; Navas, L.; Esposito, S.; et al. MicroRNA-199b-5p impairs cancer stem cells through negative regulation of HES1 in medulloblastoma. PLoS One 2009, 4, e4998.

110. Weeraratne, S.D.; Amani, V.; Neiss, A.; Teider, N.; Scott, D.K.; Pomeroy, S.L.; Cho, Y.J. miR-34a confers chemosensitivity through modulation of MAGE-A and p53 in medulloblastoma. Neuro-Oncology 2011, 13, 165-175.

111. Fiaschetti, G.; Abela, L.; Nonoguchi, N.; Dubuc, A.M.; Remke, M.; Boro, A.; Grunder, E.; Siler, U.; Ohgaki, H.; Taylor, M.D.; et al. Epigenetic silencing of miRNA-9 is associated with HES1 oncogenic activity and poor prognosis of medulloblastoma. Br. J. Cancer 2014, 110, 636-647.

112. Kefas, B.; Godlewski, J.; Comeau, L.; Li, Y.; Abounader, R.; Hawkinson, M.; Lee, J.; Fine, H.; Chiocca, E.A.; Lawler, S.; et al. microRNA-7 inhibits the epidermal growth factor receptor and the Akt pathway and is down-regulated in glioblastoma. Cancer Res. 2008, 68, 3566-3572.

113. Li, K.K.; Pang, J.C.; Ching, A.K.; Wong, C.K.; Kong, X.; Wang, Y.; Zhou, L.; Chen, Z.; Ng, H.K. miR-124 is frequently down-regulated in medulloblastoma and is a negative regulator of SLC16A1. Hum. Pathol. 2009, 40, 1234-1243.

114. Yoo, A.S.; Staahl, B.T.; Chen, L.; Crabtree, G.R. MicroRNA-mediated switching of chromatin-remodelling complexes in neural development. Nature 2009, 460, 642-646.

115. Lu, Y.; Ryan, S.L.; Elliott, D.J.; Bignell, G.R.; Futreal, P.A.; Ellison, D.W.; Bailey, S.; Clifford, S.C. Amplification and overexpression of Hsa-miR-30b, Hsa-miR-30d and KHDRBS3 at 8q24.22-q24.23 in medulloblastoma. PLoS One 2009, 4, e6159.

116. Liu, W.; Gong, Y.H.; Chao, T.F.; Peng, X.Z.; Yuan, J.G.; Ma, Z.Y.; Jia, G.; Zhao, J.Z. Identification of differentially expressed microRNAs by microarray: A possible role for microRNAs gene in medulloblastomas. Chin. Med. J. 2009, 122, 2405-2411.

117. Wei, J.S.; Johansson, P.; Chen, Q.R.; Song, Y.K.; Durinck, S.; Wen, X.; Cheuk, A.T.; Smith, M.A.; Houghton, P.; Morton, C.; et al. microRNA profiling identifies cancer-specific and prognostic signatures in pediatric malignancies. Clin. Cancer Res. 2009, 15, 5560-5568.

118. Venkataraman, S.; Alimova, I.; Fan, R.; Harris, P.; Foreman, N.; Vibhakar, R. MicroRNA 128a increases intracellular ROS level by targeting Bmi-1 and inhibits medulloblastoma cancer cell growth by promoting senescence. PLoS One 2010, 5, e10748. 
119. Weeraratne, S.D.; Amani, V.; Teider, N.; Pierre-Francois, J.; Winter, D.; Kye, M.J.; Sengupta, S.; Archer, T.; Remke, M.; Bai, A.H.; et al. Pleiotropic effects of miR-183 96 182 converge to regulate cell survival, proliferation and migration in medulloblastoma. Acta Neuropathol. 2012, 123, 539-552.

120. Gokhale, A.; Kunder, R.; Goel, A.; Sarin, R.; Moiyadi, A.; Shenoy, A.; Mamidipally, C.; Noronha, S.; Kannan, S.; Shirsat, N.V. Distinctive microRNA signature of medulloblastomas associated with the WNT signaling pathway. J. Cancer Res. Ther. 2010, 6, 521-529.

121. Li, M.; Lee, K.F.; Lu, Y.; Clarke, I.; Shih, D.; Eberhart, C.; Collins, V.P.; van Meter, T.; Picard, D.; Zhou, L.; et al. Frequent amplification of a chr19q13.41 microRNA polycistron in aggressive primitive neuroectodermal brain tumors. Cancer Cell 2009, 16, 533-546.

122. Wang, F.; Xue, X.; Wei, J.; An, Y.; Yao, J.; Cai, H.; Wu, J.; Dai, C.; Qian, Z.; Xu, Z.; et al. hsa-miR-520h downregulates ABCG2 in pancreatic cancer cells to inhibit migration, invasion, and side populations. Br. J. Cancer 2010, 103, 567-574.

123. Sredni, S.T.; Bonaldo Mde, F.; Costa, F.F.; Huang, C.C.; Hamm, C.A.; Rajaram, V.; Tomita, T.; Goldman, S.; Bischof, J.M.; Soares, M.B. Upregulation of mir-221 and mir-222 in atypical teratoid/rhabdoid tumors: Potential therapeutic targets. Childs Nerv. Syst. 2010, 26, 279-283.

124. Zhang, K.; Gao, H.; Wu, X.; Wang, J.; Zhou, W.; Sun, G.; Wang, J.; Wang, Y.; Mu, B.; Kim, C.; et al. Frequent overexpression of HMGA2 in human atypical teratoid/rhabdoid tumor and its correlation with let-7a3/let-7b miRNA. Clin. Cancer Res. 2014, 20, 1179-1189.

125. Schulte, J.H.; Marschall, T.; Martin, M.; Rosenstiel, P.; Mestdagh, P.; Schlierf, S.; Thor, T.; Vandesompele, J.; Eggert, A.; Schreiber, S.; et al. Deep sequencing reveals differential expression of microRNAs in favorable versus unfavorable neuroblastoma. Nucleic Acids Res. 2010, 38, 5919-5928.

126. De Brouwer, S.; Mestdagh, P.; Lambertz, I.; Pattyn, F.; de Paepe, A.; Westermann, F.; Schroeder, C.; Schulte, J.H.; Schramm, A.; de Preter, K.; et al. Dickkopf-3 is regulated by the MYCN-induced miR-17-92 cluster in neuroblastoma. Int. J. Cancer 2012, 130, 2591-2598.

127. Stallings, R.L. MicroRNA involvement in the pathogenesis of neuroblastoma: Potential for microRNA mediated therapeutics. Curr. Pharm. Des. 2009, 15, 456-462.

128. Mestdagh, P.; Fredlund, E.; Pattyn, F.; Schulte, J.H.; Muth, D.; Vermeulen, J.; Kumps, C.; Schlierf, S.; de Preter, K.; van Roy, N.; et al. MYCN/c-MYC-induced microRNAs repress coding gene networks associated with poor outcome in MYCN/c-MYC-activated tumors. Oncogene 2010, 29, 1394-1404.

129. Chen, Y.; Tsai, Y.H.; Fang, Y.; Tseng, S.H. Micro-RNA-21 regulates the sensitivity to cisplatin in human neuroblastoma cells. J. Pediatr. Surg. 2012, 47, 1797-1805.

130. Huang, T.C.; Chang, H.Y.; Chen, C.Y.; Wu, P.Y.; Lee, H.; Liao, Y.F.; Hsu, W.M.; Huang, H.C.; Juan, H.F. Silencing of miR-124 induces neuroblastoma SK-N-SH cell differentiation, cell cycle arrest and apoptosis through promoting AHR. FEBS Lett. 2011, 585, 3582-3586.

131. Mestdagh, P.; Bostrom, A.K.; Impens, F.; Fredlund, E.; van Peer, G.; de Antonellis, P.; von Stedingk, K.; Ghesquiere, B.; Schulte, S.; Dews, M.; et al. The miR-17-92 microRNA cluster regulates multiple components of the TGF-beta pathway in neuroblastoma. Mol. Cell 2010, 40, 762-773. 
132. Swarbrick, A.; Woods, S.L.; Shaw, A.; Balakrishnan, A.; Phua, Y.; Nguyen, A.; Chanthery, Y.; Lim, L.; Ashton, L.J.; Judson, R.L.; et al. miR-380-5p represses p53 to control cellular survival and is associated with poor outcome in MYCN-amplified neuroblastoma. Nat. Med. 2010, 16, 1134-1140.

133. Xin, C.; Buhe, B.; Hongting, L.; Chuanmin, Y.; Xiwei, H.; Hong, Z.; Lulu, H.; Qian, D.; Renjie, W. MicroRNA-15a promotes neuroblastoma migration by targeting reversion-inducing cysteine-rich protein with Kazal motifs (RECK) and regulating matrix metalloproteinase-9 expression. FEBS J. 2013, 280, 855-866.

134. Schulte, J.H.; Horn, S.; Schlierf, S.; Schramm, A.; Heukamp, L.C.; Christiansen, H.; Buettner, R.; Berwanger, B.; Eggert, A. MicroRNAs in the pathogenesis of neuroblastoma. Cancer Lett. 2009, 274, 10-15.

135. Tivnan, A.; Foley, N.H.; Tracey, L.; Davidoff, A.M.; Stallings, R.L. MicroRNA-184-mediated inhibition of tumour growth in an orthotopic murine model of neuroblastoma. Anticancer Res. 2010, 30, 4391-4395.

136. Evangelisti, C.; Florian, M.C.; Massimi, I.; Dominici, C.; Giannini, G.; Galardi, S.; Bue, M.C.; Massalini, S.; McDowell, H.P.; Messi, E.; et al. MiR-128 up-regulation inhibits Reelin and DCX expression and reduces neuroblastoma cell motility and invasiveness. FASEB J. 2009, 23, 4276-4287.

137. Gattolliat, C.H.; Thomas, L.; Ciafre, S.A.; Meurice, G.; Le Teuff, G.; Job, B.; Richon, C.; Combaret, V.; Dessen, P.; Valteau-Couanet, D.; et al. Expression of miR-487b and miR-410 encoded by $14 \mathrm{q} 32.31$ locus is a prognostic marker in neuroblastoma. Br. J. Cancer 2011, 105, 1352-1361.

138. Cole, K.A.; Attiyeh, E.F.; Mosse, Y.P.; Laquaglia, M.J.; Diskin, S.J.; Brodeur, G.M.; Maris, J.M. A functional screen identifies miR-34a as a candidate neuroblastoma tumor suppressor gene. Mol. Cancer Res. 2008, 6, 735-742.

139. Chen, Y.; Tsai, Y.H.; Tseng, S.H. Inhibition of cyclin-dependent kinase 1-induced cell death in neuroblastoma cells through the microRNA-34a-MYCN-survivin pathway. Surgery 2013, 153, 4-16.

140. Bray, I.; Tivnan, A.; Bryan, K.; Foley, N.H.; Watters, K.M.; Tracey, L.; Davidoff, A.M.; Stallings, R.L. MicroRNA-542-5p as a novel tumor suppressor in neuroblastoma. Cancer Lett. 2011, 303, 56-64.

141. Buechner, J.; Tomte, E.; Haug, B.H.; Henriksen, J.R.; Lokke, C.; Flaegstad, T.; Einvik, C. Tumour-suppressor microRNAs let-7 and mir-101 target the proto-oncogene MYCN and inhibit cell proliferation in MYCN-amplified neuroblastoma. Br. J. Cancer 2011, 105, 296-303.

142. Afanasyeva, E.A.; Mestdagh, P.; Kumps, C.; Vandesompele, J.; Ehemann, V.; Theissen, J.; Fischer, M.; Zapatka, M.; Brors, B.; Savelyeva, L.; et al. MicroRNA miR-885-5p targets CDK2 and MCM5, activates p53 and inhibits proliferation and survival. Cell Death Differ. 2011, 18, 974-984.

143. Lee, J.J.; Drakaki, A.; Iliopoulos, D.; Struhl, K. MiR-27b targets PPARgamma to inhibit growth, tumor progression and the inflammatory response in neuroblastoma cells. Oncogene 2012, 31, $3818-3825$. 
144. Chakrabarti, M.; Banik, N.L.; Ray, S.K. miR-138 overexpression is more powerful than hTERT knockdown to potentiate apigenin for apoptosis in neuroblastoma in vitro and in vivo. Exp. Cell Res. 2013, 319, 1575-1585.

145. Althoff, K.; Beckers, A.; Odersky, A.; Mestdagh, P.; Koster, J.; Bray, I.M.; Bryan, K.; Vandesompele, J.; Speleman, F.; Stallings, R.L.; et al. MiR-137 functions as a tumor suppressor in neuroblastoma by downregulating KDM1A. Int. J. Cancer 2013, 133, 1064-1073.

146. Ryan, J.; Tivnan, A.; Fay, J.; Bryan, K.; Meehan, M.; Creevey, L.; Lynch, J.; Bray, I.M.; O'Meara, A.; Davidoff, A.M.; et al. MicroRNA-204 increases sensitivity of neuroblastoma cells to cisplatin and is associated with a favourable clinical outcome. Br. J. Cancer 2012, 107, 967-976.

147. Slaby, O. MiR-190 leads to aggressive phenotype of neuroblastoma through indirect activation of TrkB pathway. Med. Hypotheses 2013, 80, 325-326.

148. Foley, N.H.; Bray, I.; Watters, K.M.; Das, S.; Bryan, K.; Bernas, T.; Prehn, J.H.; Stallings, R.L. MicroRNAs $10 \mathrm{a}$ and $10 \mathrm{~b}$ are potent inducers of neuroblastoma cell differentiation through targeting of nuclear receptor corepressor 2. Cell Death Differ. 2011, 18, 1089-1098.

149. Qiao, J.; Lee, S.; Paul, P.; Theiss, L.; Tiao, J.; Qiao, L.; Kong, A.; Chung, D.H. miR-335 and miR-363 regulation of neuroblastoma tumorigenesis and metastasis. Surgery 2013, 154, 226-233.

150. Lynch, J.; Fay, J.; Meehan, M.; Bryan, K.; Watters, K.M.; Murphy, D.M.; Stallings, R.L. MiRNA-335 suppresses neuroblastoma cell invasiveness by direct targeting of multiple genes from the non-canonical TGF-beta signalling pathway. Carcinogenesis 2012, 33, 976-985.

151. Zhang, H.; Qi, M.; Li, S.; Qi, T.; Mei, H.; Huang, K.; Zheng, L.; Tong, Q. microRNA-9 targets matrix metalloproteinase 14 to inhibit invasion, metastasis, and angiogenesis of neuroblastoma cells. Mol. Cancer Ther. 2012, 11, 1454-1466.

152. Zhang, H.; Pu, J.; Qi, T.; Qi, M.; Yang, C.; Li, S.; Huang, K.; Zheng, L.; Tong, Q. MicroRNA-145 inhibits the growth, invasion, metastasis and angiogenesis of neuroblastoma cells through targeting hypoxia-inducible factor 2 alpha. Oncogene 2014, 33, 387-397.

153. Guo, J.; Dong, Q.; Fang, Z.; Chen, X.; Lu, H.; Wang, K.; Yin, Y.; Cai, X.; Zhao, N.; Chen, J.; et al. Identification of miRNAs that are associated with tumor metastasis in neuroblastoma. Cancer Biol. Ther. 2010, 9, 446-452.

154. Loven, J.; Zinin, N.; Wahlstrom, T.; Muller, I.; Brodin, P.; Fredlund, E.; Ribacke, U.; Pivarcsi, A.; Pahlman, S.; Henriksson, M. MYCN-regulated microRNAs repress estrogen receptor-alpha (ESR1) expression and neuronal differentiation in human neuroblastoma. Proc. Natl. Acad. Sci. USA 2010, 107, 1553-1558.

155. Schulte, J.H.; Schowe, B.; Mestdagh, P.; Kaderali, L.; Kalaghatgi, P.; Schlierf, S.; Vermeulen, J.; Brockmeyer, B.; Pajtler, K.; Thor, T.; et al. Accurate prediction of neuroblastoma outcome based on miRNA expression profiles. Int. J. Cancer 2010, 127, 2374-2385.

156. Bienertova-Vasku, J.; Mazanek, P.; Hezova, R.; Curdova, A.; Nekvindova, J.; Kren, L.; Sterba, J.; Slaby, O. Extension of microRNA expression pattern associated with high-risk neuroblastoma. Tumour Biol. 2013, 34, 2315-2319.

157. Lin, R.J.; Lin, Y.C.; Chen, J.; Kuo, H.H.; Chen, Y.Y.; Diccianni, M.B.; London, W.B.; Chang, C.H.; Yu, A.L. microRNA signature and expression of Dicer and Drosha can predict prognosis and delineate risk groups in neuroblastoma. Cancer Res. 2010, 70, 7841-7850. 
158. De Preter, K.; Mestdagh, P.; Vermeulen, J.; Zeka, F.; Naranjo, A.; Bray, I.; Castel, V.; Chen, C.; Drozynska, E.; Eggert, A.; et al. miRNA expression profiling enables risk stratification in archived and fresh neuroblastoma tumor samples. Clin. Cancer Res. 2011, 17, 7684-7692.

159. Buckley, P.G.; Alcock, L.; Bryan, K.; Bray, I.; Schulte, J.H.; Schramm, A.; Eggert, A.; Mestdagh, P.; de Preter, K.; Vandesompele, J.; et al. Chromosomal and microRNA expression patterns reveal biologically distinct subgroups of 11q- neuroblastoma. Clin. Cancer Res. 2010, 16, 2971-2978.

160. Kunder, R.; Jalali, R.; Sridhar, E.; Moiyadi, A.; Goel, N.; Goel, A.; Gupta, T.; Krishnatry, R.; Kannan, S.; Kurkure, P.; et al. Real-time PCR assay based on the differential expression of microRNAs and protein-coding genes for molecular classification of formalin-fixed paraffin embedded medulloblastomas. Neuro-Oncology 2013, 15, 1644-1651.

161. Chan, J.A.; Krichevsky, A.M.; Kosik, K.S. MicroRNA-21 is an antiapoptotic factor in human glioblastoma cells. Cancer Res. 2005, 65, 6029-6033.

162. Uziel, T.; Karginov, F.V.; Xie, S.; Parker, J.S.; Wang, Y.D.; Gajjar, A.; He, L.; Ellison, D.; Gilbertson, R.J.; Hannon, G.; et al. The miR-17 92 cluster collaborates with the Sonic Hedgehog pathway in medulloblastoma. Proc. Natl. Acad. Sci. USA 2009, 106, 2812-2817.

163. Northcott, P.A.; Nakahara, Y.; Wu, X.; Feuk, L.; Ellison, D.W.; Croul, S.; Mack, S.; Kongkham, P.N.; Peacock, J.; Dubuc, A.; et al. Multiple recurrent genetic events converge on control of histone lysine methylation in medulloblastoma. Nat. Genet. 2009, 41, 465-472.

164. Murphy, B.L.; Obad, S.; Bihannic, L.; Ayrault, O.; Zindy, F.; Kauppinen, S.; Roussel, M.F. Silencing of the miR-17 92 cluster family inhibits medulloblastoma progression. Cancer Res. 2013, 73, 7068-7078.

165. Roussel, M.F.; Robinson, G.W. Role of MYC in Medulloblastoma. Cold Spring Harb. Perspect. Med. 2013, 3, doi:10.1101/cshperspect.a014308.

166. Bai, A.H.; Milde, T.; Remke, M.; Rolli, C.G.; Hielscher, T.; Cho, Y.J.; Kool, M.; Northcott, P.A.; Jugold, M.; Bazhin, A.V.; et al. MicroRNA-182 promotes leptomeningeal spread of non-sonic hedgehog-medulloblastoma. Acta Neuropathol. 2012, 123, 529-538.

167. Cho, Y.J.; Tsherniak, A.; Tamayo, P.; Santagata, S.; Ligon, A.; Greulich, H.; Berhoukim, R.; Amani, V.; Goumnerova, L.; Eberhart, C.G.; et al. Integrative genomic analysis of medulloblastoma identifies a molecular subgroup that drives poor clinical outcome. J. Clin. Oncol. 2011, 29, 1424-1430.

168. Grunwald, I.; Dillmann, K.; Roth, C.; Backens, M.; Reith, W. Supratentorial tumors. Radiologe 2007, 47, 471-485.

169. Allen, J.C.; Judkins, A.R.; Rosenblum, M.K.; Biegel, J.A. Atypical teratoid/rhabdoid tumor evolving from an optic pathway ganglioglioma: Case study. Neuro-Oncology 2006, 8, 79-82.

170. Li, M.H.; Bouffet, E.; Hawkins, C.E.; Squire, J.A.; Huang, A. Molecular genetics of supratentorial primitive neuroectodermal tumors and pineoblastoma. Neurosurg. Focus 2005, 19, E3.

171. Nobusawa, S.; Yokoo, H.; Hirato, J.; Kakita, A.; Takahashi, H.; Sugino, T.; Tasaki, K.; Itoh, H.; Hatori, T.; Shimoyama, Y.; et al. Analysis of chromosome 19q13.42 amplification in embryonal brain tumors with ependymoblastic multilayered rosettes. Brain Pathol. 2012, 22, 689-697. 
172. Korshunov, A.; Remke, M.; Gessi, M.; Ryzhova, M.; Hielscher, T.; Witt, H.; Tobias, V.; Buccoliero, A.M.; Sardi, I.; Gardiman, M.P.; et al. Focal genomic amplification at 19q13.42 comprises a powerful diagnostic marker for embryonal tumors with ependymoblastic rosettes. Acta Neuropathol. 2010, 120, 253-260.

173. Kleinman, C.L.; Gerges, N.; Papillon-Cavanagh, S.; Sin-Chan, P.; Pramatarova, A.; Quang, D.A.; Adoue, V.; Busche, S.; Caron, M.; Djambazian, H.; et al. Fusion of TTYH1 with the C19MC microRNA cluster drives expression of a brain-specific DNMT3B isoform in the embryonal brain tumor ETMR. Nat. Genet. 2014, 46, 39-44.

174. Archer, T.C.; Pomeroy, S.L. A developmental program drives aggressive embryonal brain tumors. Nat. Genet. 2014, 46, 2-3.

175. Rorke, L.B.; Packer, R.J.; Biegel, J.A. Central nervous system atypical teratoid/rhabdoid tumors of infancy and childhood: Definition of an entity. J. Neurosurg. 1996, 85, 56-65.

176. Reddy, A.T. Atypical teratoid/rhabdoid tumors of the central nervous system. J. Neuro-Oncol. 2005, 75, 309-313.

177. Oda, Y.; Tsuneyoshi, M. Extrarenal rhabdoid tumors of soft tissue: Clinicopathological and molecular genetic review and distinction from other soft-tissue sarcomas with rhabdoid features. Pathol. Int. 2006, 56, 287-295.

178. Versteege, I.; Sevenet, N.; Lange, J.; Rousseau-Merck, M.F.; Ambros, P.; Handgretinger, R.; Aurias, A.; Delattre, O. Truncating mutations of hSNF5/INI1 in aggressive paediatric cancer. Nature 1998, 394, 203-206.

179. Biegel, J.A.; Tan, L.; Zhang, F.; Wainwright, L.; Russo, P.; Rorke, L.B. Alterations of the hSNF5/INI1 gene in central nervous system atypical teratoid/rhabdoid tumors and renal and extrarenal rhabdoid tumors. Clin. Cancer Res. 2002, 8, 3461-3467.

180. Bambakidis, N.C.; Robinson, S.; Cohen, M.; Cohen, A.R. Atypical teratoid/rhabdoid tumors of the central nervous system: Clinical, radiographic and pathologic features. Pediatr. Neurosurg. 2002, 37, 64-70.

181. Hilden, J.M.; Meerbaum, S.; Burger, P.; Finlay, J.; Janss, A.; Scheithauer, B.W.; Walter, A.W.; Rorke, L.B.; Biegel, J.A. Central nervous system atypical teratoid/rhabdoid tumor: Results of therapy in children enrolled in a registry. J. Clin. Oncol. 2004, 22, 2877-2884.

182. Tekautz, T.M.; Fuller, C.E.; Blaney, S.; Fouladi, M.; Broniscer, A.; Merchant, T.E.; Krasin, M.; Dalton, J.; Hale, G.; Kun, L.E.; et al. Atypical teratoid/rhabdoid tumors (ATRT): Improved survival in children 3 years of age and older with radiation therapy and high-dose alkylator-based chemotherapy. J. Clin. Oncol. 2005, 23, 1491-1499.

183. Brodeur, G.M. Neuroblastoma: Biological insights into a clinical enigma. Nat. Rev. Cancer 2003, 3, 203-216.

184. Maris, J.M.; Hogarty, M.D.; Bagatell, R.; Cohn, S.L. Neuroblastoma. Lancet 2007, 369 , 2106-2120.

185. Schor, N.F. Neuroblastoma as a neurobiological disease. J. Neuro-Oncol. 1999, 41, 159-166.

186. Evans, A.E.; D’Angio, G.J.; Randolph, J. A proposed staging for children with neuroblastoma. Children's cancer study group A. Cancer 1971, 27, 374-378.

187. Nakagawara, A.; Ohira, M. Comprehensive genomics linking between neural development and cancer: Neuroblastoma as a model. Cancer Lett. 2004, 204, 213-224. 
188. Johnsen, J.I.; Kogner, P.; Albihn, A.; Henriksson, M.A. Embryonal neural tumours and cell death. Apoptosis 2009, 14, 424-438.

189. Jiang, M.; Stanke, J.; Lahti, J.M. The connections between neural crest development and neuroblastoma. Curr. Top. Dev. Biol. 2011, 94, 77-127.

190. Maris, J.M. The biologic basis for neuroblastoma heterogeneity and risk stratification. Curr. Opin. Pediatr. 2005, 17, 7-13.

191. Bordow, S.B.; Norris, M.D.; Haber, P.S.; Marshall, G.M.; Haber, M. Prognostic significance of MYCN oncogene expression in childhood neuroblastoma. J. Clin. Oncol. 1998, 16, 3286-3294.

192. Cohn, S.L.; London, W.B.; Huang, D.; Katzenstein, H.M.; Salwen, H.R.; Reinhart, T.; Madafiglio, J.; Marshall, G.M.; Norris, M.D.; Haber, M. MYCN expression is not prognostic of adverse outcome in advanced-stage neuroblastoma with nonamplified MYCN. J. Clin. Oncol. 2000, 18, 3604-3613.

193. Chen, Y.; Stallings, R.L. Differential patterns of microRNA expression in neuroblastoma are correlated with prognosis, differentiation, and apoptosis. Cancer Res. 2007, 67, 976-983.

194. Zhang, H.; Li, Y.; Lai, M. The microRNA network and tumor metastasis. Oncogene 2010, 29, 937-948.

195. Gebeshuber, C.A.; Zatloukal, K.; Martinez, J. miR-29a suppresses tristetraprolin, which is a regulator of epithelial polarity and metastasis. EMBO Rep. 2009, 10, 400-405.

196. Buechner, J.; Einvik, C. N-myc and noncoding RNAs in neuroblastoma. Mol. Cancer Res. 2012, $10,1243-1253$.

197. Fontana, L.; Fiori, M.E.; Albini, S.; Cifaldi, L.; Giovinazzi, S.; Forloni, M.; Boldrini, R.; Donfrancesco, A.; Federici, V.; Giacomini, P.; et al. Antagomir-17-5p abolishes the growth of therapy-resistant neuroblastoma through p21 and BIM. PLoS One 2008, 3, e2236.

198. Schulte, J.H.; Horn, S.; Otto, T.; Samans, B.; Heukamp, L.C.; Eilers, U.C.; Krause, M.; Astrahantseff, K.; Klein-Hitpass, L.; Buettner, R.; et al. MYCN regulates oncogenic MicroRNAs in neuroblastoma. Int. J. Cancer 2008, 122, 699-704.

199. Mestdagh, P.; van Vlierberghe, P.; de Weer, A.; Muth, D.; Westermann, F.; Speleman, F.; Vandesompele, J. A novel and universal method for microRNA RT-qPCR data normalization. Genome Biol. 2009, 10, R64, doi:10.1186/gb-2009-10-6-r64.

200. Bray, I.; Bryan, K.; Prenter, S.; Buckley, P.G.; Foley, N.H.; Murphy, D.M.; Alcock, L.; Mestdagh, P.; Vandesompele, J.; Speleman, F.; et al. Widespread dysregulation of MiRNAs by MYCN amplification and chromosomal imbalances in neuroblastoma: Association of miRNA expression with survival. PLoS One 2009, 4, e7850.

201. Shohet, J.M.; Ghosh, R.; Coarfa, C.; Ludwig, A.; Benham, A.L.; Chen, Z.; Patterson, D.M.; Barbieri, E.; Mestdagh, P.; Sikorski, D.N.; et al. A genome-wide search for promoters that respond to increased MYCN reveals both new oncogenic and tumor suppressor microRNAs associated with aggressive neuroblastoma. Cancer Res. 2011, 71, 3841-3851.

202. Haug, B.H.; Henriksen, J.R.; Buechner, J.; Geerts, D.; Tomte, E.; Kogner, P.; Martinsson, T.; Flaegstad, T.; Sveinbjornsson, B.; Einvik, C. MYCN-regulated miRNA-92 inhibits secretion of the tumor suppressor DICKKOPF-3 (DKK3) in neuroblastoma. Carcinogenesis 2011, 32, 1005-1012. 
203. Foley, N.H.; Bray, I.M.; Tivnan, A.; Bryan, K.; Murphy, D.M.; Buckley, P.G.; Ryan, J.; O’Meara, A.; O’Sullivan, M.; Stallings, R.L. MicroRNA-184 inhibits neuroblastoma cell survival through targeting the serine/threonine kinase AKT2. Mol. Cancer 2010, 9, 83, doi:10.1186/1476-4598-9-83.

204. Bian, S.; Hong, J.; Li, Q.; Schebelle, L.; Pollock, A.; Knauss, J.L.; Garg, V.; Sun, T. MicroRNA cluster miR-17-92 regulates neural stem cell expansion and transition to intermediate progenitors in the developing mouse neocortex. Cell Rep. 2013, 3, 1398-1406.

205. Cho, W.C. MicroRNAs: Potential biomarkers for cancer diagnosis, prognosis and targets for therapy. Int. J. Biochem. Cell Biol. 2010, 42, 1273-1281.

206. Mitchell, P.S.; Parkin, R.K.; Kroh, E.M.; Fritz, B.R.; Wyman, S.K.; Pogosova-Agadjanyan, E.L.; Peterson, A.; Noteboom, J.; O’Briant, K.C.; Allen, A.; et al. Circulating microRNAs as stable blood-based markers for cancer detection. Proc. Natl. Acad. Sci. USA 2008, 105, 10513-10518.

207. White, N.M.; Bao, T.T.; Grigull, J.; Youssef, Y.M.; Girgis, A.; Diamandis, M.; Fatoohi, E.; Metias, M.; Honey, R.J.; Stewart, R.; et al. miRNA profiling for clear cell renal cell carcinoma: Biomarker discovery and identification of potential controls and consequences of miRNA dysregulation. J. Urol. 2011, 186, 1077-1083.

208. Heneghan, H.M.; Miller, N.; Kelly, R.; Newell, J.; Kerin, M.J. Systemic miRNA-195 differentiates breast cancer from other malignancies and is a potential biomarker for detecting noninvasive and early stage disease. Oncologist 2010, 15, 673-682.

209. Nass, D.; Rosenwald, S.; Meiri, E.; Gilad, S.; Tabibian-Keissar, H.; Schlosberg, A.; Kuker, H.; Sion-Vardy, N.; Tobar, A.; Kharenko, O.; et al. MiR-92b and miR-9/9* are specifically expressed in brain primary tumors and can be used to differentiate primary from metastatic brain tumors. Brain Pathol. 2009, 19, 375-383.

210. Osaki, M.; Takeshita, F.; Ochiya, T. MicroRNAs as biomarkers and therapeutic drugs in human cancer. Biomarkers 2008, 13, 658-670.

211. Wang, J.; Chen, J.; Chang, P.; LeBlanc, A.; Li, D.; Abbruzzesse, J.L.; Frazier, M.L.; Killary, A.M.; Sen, S. MicroRNAs in plasma of pancreatic ductal adenocarcinoma patients as novel blood-based biomarkers of disease. Cancer Prev. Res. 2009, 2, 807-813.

212. Kanaan, Z.; Roberts, H.; Eichenberger, M.R.; Billeter, A.; Ocheretner, G.; Pan, J.; Rai, S.N.; Jorden, J.; Williford, A.; Galandiuk, S. A plasma microRNA panel for detection of colorectal adenomas: A step toward more precise screening for colorectal cancer. Ann. Surg. 2013, 258, 400-408.

213. Teplyuk, N.M.; Mollenhauer, B.; Gabriely, G.; Giese, A.; Kim, E.; Smolsky, M.; Kim, R.Y.; Saria, M.G.; Pastorino, S.; Kesari, S.; et al. MicroRNAs in cerebrospinal fluid identify glioblastoma and metastatic brain cancers and reflect disease activity. Neuro-Oncology 2012, 14, 689-700.

214. Baraniskin, A.; Kuhnhenn, J.; Schlegel, U.; Maghnouj, A.; Zollner, H.; Schmiegel, W.; Hahn, S.; Schroers, R. Identification of microRNAs in the cerebrospinal fluid as biomarker for the diagnosis of glioma. Neuro-Oncology 2012, 14, 29-33.

215. Cho, W.C. Circulating MicroRNAs as Minimally Invasive Biomarkers for Cancer Theragnosis and Prognosis. Front. Genet. 2011, 2, 7, doi:10.3389/fgene.2011.00007. 
216. De Smaele, E.; Ferretti, E.; Gulino, A. MicroRNAs as biomarkers for CNS cancer and other disorders. Brain Res. 2010, 1338, 100-111.

217. Jin, X.F.; Wu, N.; Wang, L.; Li, J. Circulating microRNAs: A novel class of potential biomarkers for diagnosing and prognosing central nervous system diseases. Cell. Mol. Neurobiol. 2013, 33, 601-613.

218. Chen, S.Y.; Wang, Y.; Telen, M.J.; Chi, J.T. The genomic analysis of erythrocyte microRNA expression in sickle cell diseases. PLoS One 2008, 3, e2360.

219. Wang, K.; Zhang, S.; Marzolf, B.; Troisch, P.; Brightman, A.; Hu, Z.; Hood, L.E.; Galas, D.J. Circulating microRNAs, potential biomarkers for drug-induced liver injury. Proc. Natl. Acad. Sci. USA 2009, 106, 4402-4407.

220. Cogswell, J.P.; Ward, J.; Taylor, I.A.; Waters, M.; Shi, Y.; Cannon, B.; Kelnar, K.; Kemppainen, J.; Brown, D.; Chen, C.; et al. Identification of miRNA changes in Alzheimer's disease brain and CSF yields putative biomarkers and insights into disease pathways. J. Alzheimers Dis. 2008, 14, 27-41.

221. Chen, X.; Liang, H.; Zhang, J.; Zen, K.; Zhang, C.Y. Secreted microRNAs: A new form of intercellular communication. Trends Cell Biol. 2012, 22, 125-132.

222. Chin, L.J.; Slack, F.J. A truth serum for cancer--microRNAs have major potential as cancer biomarkers. Cell Res. 2008, 18, 983-984.

223. Mathivanan, S.; Ji, H.; Simpson, R.J. Exosomes: Extracellular organelles important in intercellular communication. J. Proteomics 2010, 73, 1907-1920.

224. Valadi, H.; Ekstrom, K.; Bossios, A.; Sjostrand, M.; Lee, J.J.; Lotvall, J.O. Exosome-mediated transfer of mRNAs and microRNAs is a novel mechanism of genetic exchange between cells. Nat. Cell Biol. 2007, 9, 654-659.

225. Vickers, K.C.; Palmisano, B.T.; Shoucri, B.M.; Shamburek, R.D.; Remaley, A.T. MicroRNAs are transported in plasma and delivered to recipient cells by high-density lipoproteins. Nat. Cell Biol. 2011, 13, 423-433.

226. Hannafon, B.N.; Ding, W.Q. Intercellular Communication by Exosome-Derived microRNAs in Cancer. Int. J. Mol. Sci. 2013, 14, 14240-14269.

227. Mittelbrunn, M.; Sanchez-Madrid, F. Intercellular communication: Diverse structures for exchange of genetic information. Nat. Rev. Mol. Cell Biol. 2012, 13, 328-335.

228. Scaruffi, P.; Stigliani, S.; Moretti, S.; Coco, S.; de Vecchi, C.; Valdora, F.; Garaventa, A.; Bonassi, S.; Tonini, G.P. Transcribed-Ultra Conserved Region expression is associated with outcome in high-risk neuroblastoma. BMC Cancer 2009, 9, 441, doi:10.1186/1471-2407-9-441.

229. Creevey, L.; Ryan, J.; Harvey, H.; Bray, I.M.; Meehan, M.; Khan, A.R.; Stallings, R.L. MicroRNA-497 increases apoptosis in MYCN amplified neuroblastoma cells by targeting the key cell cycle regulator WEE1. Mol. Cancer 2013, 12, 23, doi:10.1186/1476-4598-12-23.

230. Vermeulen, J.; de Preter, K.; Mestdagh, P.; Laureys, G.; Speleman, F.; Vandesompele, J. Predicting outcomes for children with neuroblastoma. Discov. Med. 2010, 10, 29-36.

231. Northcott, P.A.; Hielscher, T.; Dubuc, A.; Mack, S.; Shih, D.; Remke, M.; Al-Halabi, H.; Albrecht, S.; Jabado, N.; Eberhart, C.G.; et al. Pediatric and adult sonic hedgehog medulloblastomas are clinically and molecularly distinct. Acta Neuropathol. 2011, 122, 231-240. 
232. Lu, J.; Getz, G.; Miska, E.A.; Alvarez-Saavedra, E.; Lamb, J.; Peck, D.; Sweet-Cordero, A.; Ebert, B.L.; Mak, R.H.; Ferrando, A.A.; et al. MicroRNA expression profiles classify human cancers. Nature 2005, 435, 834-838.

233. Zhao, Z.; Moley, K.H.; Gronowski, A.M. Diagnostic potential for miRNAs as biomarkers for pregnancy-specific diseases. Clin. Biochem. 2013, 46, 953-960.

234. Gandellini, P.; Profumo, V.; Folini, M.; Zaffaroni, N. MicroRNAs as new therapeutic targets and tools in cancer. Expert Opin. Ther. Targets 2011, 15, 265-79.

235. Li, J.; Yuan, X.; Liu, J.; Li, Y. Medulloblastoma Treatment using Gene Therapy. J. Gene Ther. 2013, 1,6 .

236. De Antonellis, P.; Medaglia, C.; Cusanelli, E.; Andolfo, I.; Liguori, L.; de Vita, G.; Carotenuto, M.; Bello, A.; Formiggini, F.; Galeone, A.; et al. MiR-34a targeting of Notch ligand delta-like 1 impairs CD15+/CD133+ tumor-propagating cells and supports neural differentiation in medulloblastoma. PLoS One 2011, 6, e24584.

237. Li, K.K.; Pang, J.C.; Lau, K.M.; Zhou, L.; Mao, Y.; Wang, Y.; Poon, W.S.; Ng, H.K. MiR-383 is downregulated in medulloblastoma and targets peroxiredoxin 3 (PRDX3). Brain Pathol. 2013, 23, 413-425.

238. Venkataraman, S.; Birks, D.K.; Balakrishnan, I.; Alimova, I.; Harris, P.S.; Patel, P.R.; Handler, M.H.; Dubuc, A.; Taylor, M.D.; Foreman, N.K.; et al. MicroRNA 218 acts as a tumor suppressor by targeting multiple cancer phenotype-associated genes in medulloblastoma. J. Biol. Chem. 2013, 288, 1918-1928.

239. Bader, A.G.; Brown, D.; Stoudemire, J.; Lammers, P. Developing therapeutic microRNAs for cancer. Gene Ther. 2011, 18, 1121-1126.

240. Bader, A.G.; Brown, D.; Winkler, M. The promise of microRNA replacement therapy. Cancer Res. 2010, 70, 7027-7030.

241. Krutzfeldt, J.; Rajewsky, N.; Braich, R.; Rajeev, K.G.; Tuschl, T.; Manoharan, M.; Stoffel, M. Silencing of microRNAs in vivo with "antagomirs". Nature 2005, 438, 685-689.

242. Meister, G.; Landthaler, M.; Dorsett, Y.; Tuschl, T. Sequence-specific inhibition of microRNA- and siRNA-induced RNA silencing. RNA 2004, 10, 544-550.

243. Stenvang, J.; Silahtaroglu, A.N.; Lindow, M.; Elmen, J.; Kauppinen, S. The utility of LNA in microRNA-based cancer diagnostics and therapeutics. Semin. Cancer Biol. 2008, 18, 89-102.

244. Weiler, J.; Hunziker, J.; Hall, J. Anti-miRNA oligonucleotides (AMOs): Ammunition to target miRNAs implicated in human disease? Gene Ther. 2006, 13, 496-502.

245. Zhu, S.; Wu, H.; Wu, F.; Nie, D.; Sheng, S.; Mo, Y.Y. MicroRNA-21 targets tumor suppressor genes in invasion and metastasis. Cell Res. 2008, 18, 350-359.

246. Gabriely, G.; Wurdinger, T.; Kesari, S.; Esau, C.C.; Burchard, J.; Linsley, P.S.; Krichevsky, A.M. MicroRNA 21 promotes glioma invasion by targeting matrix metalloproteinase regulators. Mol. Cell. Biol. 2008, 28, 5369-5380.

247. Moriyama, T.; Ohuchida, K.; Mizumoto, K.; Yu, J.; Sato, N.; Nabae, T.; Takahata, S.; Toma, H.; Nagai, E.; Tanaka, M. MicroRNA-21 modulates biological functions of pancreatic cancer cells including their proliferation, invasion, and chemoresistance. Mol. Cancer Ther. 2009, 8, 1067-1074. 
248. Bhardwaj, A.; Singh, S.; Singh, A.P. MicroRNA-based Cancer Therapeutics: Big Hope from Small RNAs. Mol. Cell. Pharmacol. 2010, 2, 213-219.

249. Ebert, M.S.; Neilson, J.R.; Sharp, P.A. MicroRNA sponges: Competitive inhibitors of small RNAs in mammalian cells. Nat. Methods 2007, 4, 721-726.

250. Ebert, M.S.; Sharp, P.A. MicroRNA sponges: Progress and possibilities. RNA 2010, 16, $2043-$ 2050.

251. Lu, Y.; Xiao, J.; Lin, H.; Bai, Y.; Luo, X.; Wang, Z.; Yang, B. A single anti-microRNA antisense oligodeoxyribonucleotide (AMO) targeting multiple microRNAs offers an improved approach for microRNA interference. Nucleic Acids Res. 2009, 37, e24, doi:10.1093/nar/gkn1053.

252. Gentner, B.; Schira, G.; Giustacchini, A.; Amendola, M.; Brown, B.D.; Ponzoni, M.; Naldini, L. Stable knockdown of microRNA in vivo by lentiviral vectors. Nat. Methods 2009, 6, 63-66.

253. Johnnidis, J.B.; Harris, M.H.; Wheeler, R.T.; Stehling-Sun, S.; Lam, M.H.; Kirak, O.; Brummelkamp, T.R.; Fleming, M.D.; Camargo, F.D. Regulation of progenitor cell proliferation and granulocyte function by microRNA-223. Nature 2008, 451, 1125-1129.

254. Xiao, J.; Yang, B.; Lin, H.; Lu, Y.; Luo, X.; Wang, Z. Novel approaches for gene-specific interference via manipulating actions of microRNAs: Examination on the pacemaker channel genes HCN2 and HCN4. J. Cell. Physiol. 2007, 212, 285-292.

255. Takamizawa, J.; Konishi, H.; Yanagisawa, K.; Tomida, S.; Osada, H.; Endoh, H.; Harano, T.; Yatabe, Y.; Nagino, M.; Nimura, Y.; et al. Reduced expression of the let-7 microRNAs in human lung cancers in association with shortened postoperative survival. Cancer Res. 2004, 64, 3753-3756.

256. Trang, P.; Medina, P.P.; Wiggins, J.F.; Ruffino, L.; Kelnar, K.; Omotola, M.; Homer, R.; Brown, D.; Bader, A.G.; Weidhaas, J.B.; et al. Regression of murine lung tumors by the let-7 microRNA. Oncogene 2010, 29, 1580-1587.

257. Kota, J.; Chivukula, R.R.; O’Donnell, K.A.; Wentzel, E.A.; Montgomery, C.L.; Hwang, H.W.; Chang, T.C.; Vivekanandan, P.; Torbenson, M.; Clark, K.R.; et al. Therapeutic microRNA delivery suppresses tumorigenesis in a murine liver cancer model. Cell 2009, 137, 1005-1017.

258. Wiggins, J.F.; Ruffino, L.; Kelnar, K.; Omotola, M.; Patrawala, L.; Brown, D.; Bader, A.G. Development of a lung cancer therapeutic based on the tumor suppressor microRNA-34. Cancer Res. 2010, 70, 5923-5930.

259. Ibrahim, A.F.; Weirauch, U.; Thomas, M.; Grunweller, A.; Hartmann, R.K.; Aigner, A. MicroRNA replacement therapy for miR-145 and miR-33a is efficacious in a model of colon carcinoma. Cancer Res. 2011, 71, 5214-5224.

260. Takeshita, F.; Patrawala, L.; Osaki, M.; Takahashi, R.U.; Yamamoto, Y.; Kosaka, N.; Kawamata, M.; Kelnar, K.; Bader, A.G.; Brown, D.; et al. Systemic delivery of synthetic microRNA-16 inhibits the growth of metastatic prostate tumors via downregulation of multiple cell-cycle genes. Mol. Ther. 2010, 18, 181-187.

261. Cimmino, A.; Calin, G.A.; Fabbri, M.; Iorio, M.V.; Ferracin, M.; Shimizu, M.; Wojcik, S.E.; Aqeilan, R.I.; Zupo, S.; Dono, M.; et al. miR-15 and miR-16 induce apoptosis by targeting BCL2. Proc. Natl. Acad. Sci. USA 2005, 102, 13944-13949.

262. Calin, G.A.; Dumitru, C.D.; Shimizu, M.; Bichi, R.; Zupo, S.; Noch, E.; Aldler, H.; Rattan, S.; Keating, M.; Rai, K.; et al. Frequent deletions and down-regulation of micro- RNA genes miR15 
and miR16 at 13q14 in chronic lymphocytic leukemia. Proc. Natl. Acad. Sci. USA 2002, 99, 15524-15529.

263. Bonci, D.; Coppola, V.; Musumeci, M.; Addario, A.; Giuffrida, R.; Memeo, L.; D’Urso, L.; Pagliuca, A.; Biffoni, M.; Labbaye, C.; et al. The miR-15a-miR-16-1 cluster controls prostate cancer by targeting multiple oncogenic activities. Nat. Med. 2008, 14, 1271-1277.

264. Li, C.; Feng, Y.; Coukos, G.; Zhang, L. Therapeutic microRNA strategies in human cancer. AAPS J. 2009, 11, 747-757.

265. Garzon, R.; Marcucci, G.; Croce, C.M. Targeting microRNAs in cancer: Rationale, strategies and challenges. Nat. Rev. 2010, 9, 775-789.

266. Deeken, J.F.; Loscher, W. The blood-brain barrier and cancer: Transporters, treatment, and Trojan horses. Clin. Cancer Res. 2007, 13, 1663-1674.

(C) 2014 by the authors; licensee MDPI, Basel, Switzerland. This article is an open access article distributed under the terms and conditions of the Creative Commons Attribution license (http://creativecommons.org/licenses/by/3.0/). 